\title{
ESTUDOS EM "SEMPRE-VIVAS": TAXONOMIA COM ÊNFASE NAS ESPÉCIES DE MINAS GERAIS, BRASIL ${ }^{1}$
}

\author{
Ana Maria Giulietti ${ }^{2},{ }^{3}$ \\ Maria das Graças Lapa Wanderley ${ }^{4}$ \\ Hilda Maria Longhi-Wagner ${ }^{5}$ \\ José Rubens Pirani ${ }^{2}$ \\ Lara Regina Parra ${ }^{6}$
}

Recebido em 30/7/96. Aceito em 23/12/96.

\begin{abstract}
RESUMO - (Estudos em "sempre-vivas": taxonomia com ênfase nas espécies de Minas Gerais, Brasil). "Sempre-vivas" é o nome dado no Brasil a partes de plantas, geralmente escapos e inflorescências, que conservam a aparência de estruturas vivas mesmo depois de destacadas e secas e que são comercializadas e exportadas para decoração de interiores. Folhas, frutos e sementes também são utilizados, mas em menor escala. As espécies de "sempre-vivas" são oriundas dos cerrados do Centro-Oeste e Sudeste do Brasil e, as de maior valor comercial, dos campos rupestres de Minas Gerais, Bahia e Goiás. Entre estas, predominam espécies de Eriocaulaceae, Poaceae (Gramineae), Xyridaceae, Cyperaceae e Rapateaceae, em ordem decrescente de importância. O maior centro de comercialização é a cidade de Diamantina, em Minas Gerais, com 25 espécies de Eriocaulaceae, 12 de Poaceae, 9 de Xyridaceae, 2 de Cyperaceae e 1 de Rapateaceae. São apresentadas chaves para identificação dos gêneros, baseadas em caracteres do material comercializado, além de breves descriçōes, ilustraçōes, listagem de material analisado, nomes populares e comentários sobre as espécies.
\end{abstract}

Palavras-chave: Sempre-vivas, Eriocaulaceae, Poaceae (Gramineae), Xyridaceae, Cyperaceae, Rapateaceae, Brasil

1 Parte do projeto "Sempre-vivas" financiado pela Financiadora de Estudos e Projetos (FINEP), sob a coordenação da Profa. Dra. Nanuza Luiza de Menezes. Apresentado no XLVII Congresso Nacional de Botânica, realizado em julho de 1996, na cidade de Nova Friburgo, RJ, Brasil

2 Depart. de Botânica, IB, USP, C.P. 11461, CEP 05422-970, São Paulo, SP, Brasil. Bolsista de Produtividade do $\mathrm{CNPq}$

3 Depart. de Ciências Biológicas, UEFS, Km 03, BR 116N, CEP 44031-460 Feira de Santana, BA, Brasil.

4 Instituto de Botânica - C.P. 4005, CEP 01061-970, São Paulo, SP, Brasil. Bolsista de Produtividade do $\mathrm{CNPq}$

5 Depart. de Botânica, UFRGS, Av. Paulo Gama, CEP 90046-900, Porto Alegre, RS, Brasil. Bolsista de Produtividade do CNPq

6 Pós-graduanda, IB; USP, C.P. 11461, CEP 05422-970, São Paulo, SP, Brasil 
ABSTRACT - (Studies in "sempre-vivas" (everlasting plants): taxonomy foccusing the species from Minas Gerais, Brazil). "Sempre-vivas" is the name given in Brazil to parts of plants, usually scapes and inflorescences, that conserve the appearance of the living structures even after dryed out (everlasting). They are sold locally and exported for interior decoration. In a smaller scale, leaves, fruits and seeds are also used. "Sempre-vivas" species are gathered in the savanna-like formations ("cerrados") of the Central-West and Southeast regions of Brazil, while species of greater commercial value originate from the grasslands with rocky outcrops ("campos rupestres") from the States of Minas Gerais, Bahia and Goiás. Species of Eriocaulaceae, Poaceae (Gramineae), Xyridaceae, Cyperaceae and Rapateaceae predominate in a decreasing order. The largest commercial center for this material is the city of Diamantina, in the State of Minas Gerais, where 25 species of Eriocaulaceae, 12 of Poaceae, 9 of Xyridaceae, 2 of Cyperaceae and I of Rapateaceae are commercialized. Identification keys for the genera based on characters found in the commercialized parts, brief descriptions, illustrations, list of the analysed material, popular names and comments on the species are presented.

Key words: Everlasting plants, Eriocaulaceae, Poaceae (Gramineae), Xyridaceae, Cyperaceae, Rapateaceae, Brazil

\section{Introdução}

"Sempre-vivas" são partes de plantas, geralmente escapos florais e inflorescências, que conservam a aparência de estruturas vivas mesmo depois de destacadas e secas e que são comercializadas e exportadas para decoração de interiores. Para tal fim são também utilizadas outras partes de plantas, especialmente folhas, frutos e sementes, conhecidas genericamente como "plantas secas".

Muitas das espécies de "sempre-vivas" comercializadas são oriundas dos cerrados do Centro-Oeste e Sudeste brasileiros. Contudo, é principalmente nos campos rupestres, tipo de formação que ocorre no topo de regiões montanhosas, especialmente nos Estados de Minas Gerais (MG), Bahia (BA) e Goiás (GO), que crescem as espécies de maior valor de revenda. Entre estas, predominam espécies de cinco famílias de monocotiledôneas, enumeradas a seguir pela seqüência decrescente de importância econômica: Eriocaulaceae, Poaceae (Gramineae), Xyridaceae, Cyperaceae e Rapateaceae. Com exceção das Poaceae e Cyperaceae, que apresentam inflorescências mais ramificadas e laxas, tais plantas podem ser caracterizadas pela presença de folhas em rosetas basais, do centro da qual partem um ou mais escapos, portando inflorescências geralmente densas e envolvidas por brácteas bem desenvolvidas e vistosas.

As cinco famílias botânicas mencionadas apresentam ampla distribuição geográfica no Brasil, contendo número significativo de espécies. Entretanto, poucas dessas espécies exibem os requisitos necessários para serem comercializadas como "sempre-vivas": escapos rígidos e inflorescências vistosas ou com brácteas vistosas e persistentes em Eriocaulaceae, Xyridaceae, Cyperaceae e Rapateaceae e glumas e antécios persistentes, ou inflorescências com cerdas ou espatéolas persistentes, em Poaceae.

A comercialização de "sempre-vivas" pela população que vive na Cadeia do Espinhaço (MG e BA) desenvolveu-se principalmente nas três últimas décadas e, 
certamente, é decorrente do declínio da atividade mineradora nestas áreas que conheceram grande riqueza durante os ciclos do ouro e do diamante.

Os escapos e inflorescências de Eriocaulaceae, Poaceae, Cyperaceae e Rapateaceae são coletados antes ou durante a floração, enquanto os de Xyridaceae são coletados desde a antese até a produção de frutos jovens. Contudo, a coleta é sempre feita antes do completo desenvolvimento dos frutos, o que certamente afeta sensivelmente a reprodução por sementes. A coleta de "sempre-vivas" é inteiramente baseada em extrativismo a partir das populações naturais e feita por pessoas da própria região, como meio de subsistência. Existe iniciativa privada trabalhando com cultivo de algumas espécies de Eriocaulaceae, principalmente Syngonanthus elegans (Bong.) Ruhland, apenas nas proximidades de Diamantina. $\mathrm{O}$ período principal de coleta concentra-se no primeiro semestre, quando ocorre floração da maioria das espécies de interesse econômico. O material recém-coletadoé reunido em ramalhetes e vendido ao intermediário, que faz a ligação entre o coletor e os revendedores e exportadores. Esses últimos possuem, geralmente, grandes depósitos onde se completa a secagem das plantas, além do armazenamento e embalagem. Em alguns casos, as plantas são tingidas com corantes artificiais.

A literatura referente às "sempre-vivas" e seu aproveitamento comercial é escassa, destacando-se apenas os trabalhos de Ferreira \& Saturnino (1977), onde é apresentada uma lista das espécies utilizadas em arranjos ornamentais com plantas secas de Minas Gerais, e Saturnino et al. (1977), onde são analisados dados de exportação no mesmo Estado.

Os dados aqui apresentados representam parte dos resultados de um projeto iniciado em 1984, financiado pela Financiadora de Estudos e Projetos (FINEP), que visava a obtenção de dados multidisciplinares sobre as "sempre-vivas". Aspectos referentes ao extrativismo, comercialização e exportação das espécies de Diamantina foram apresentados por Giulietti et al. (1988). Este trabalho é uma complementação do anterior e inclui descrições e comentários sobre as principais espécies de "semprevivas" comercializadas, especialmente em Minas Gerais, Bahia e Goiás.

\section{Material e métodos}

Para o levantamento qualitativo das espécies de "sempre-vivas" comercializadas foram realizadas as seguintes atividades, no período de 1984 a 1986:

a) Levantamento das espécies e local de procedência, junto aos entrepostos de Diamantina, Datas, Grão-Mogol e Joaquim Felício (MG) e Mucugê e Piatã (BA). Dados complementares foram obtidos nos entrepostos de Cristalina (GO) e Brasília (DF).

b) Coleta de material no campo nas áreas próximas dos pontos de comércio ou nas regiões de onde provinham as espécies comercializadas. Este levantamento objetivou a obtenção de espécimes inteiros para identificação taxonômica, além de observações das condições em que viviam as populações naturais e seu grau de abundância nas áreas exploradas. Para tanto, foram visitadas e estudadas as áreas 
referidas a seguir. Em Minas Gerais: Serra do Cipó (Santana do Riacho), Diamantina e arredores, Datas, Serra do Cabral (Joaquim Felício), Pedra Menina na Serra do Ambrósio (Rio Vermelho), Itamarandiba, Serras de Grão-Mogol e Itacambira. Na Bahia: áreas da Chapada Diamantina compreendidas pelas serras próximas a Mucugê, Lençóis, Piatã e Rio de Contas. Em Goiás: Cristalina e Chapada dos Veadeiros. O material coletado foi incluído nos números de coleta da "Coleção Flora de Campos Rupestres", CFCR, e na "Coleção Flora da Serra do Cipó", CFSC, sendo citado na relação de material examinado. Além desse material depositado no Herbário do Departamento de Botânica da Universidade de São Paulo (SPF), outras coleções foram estudadas, especialmente as do herbário do Instituto de Botânica de São Paulo (SP).

c) Estudo das espécies levantadas, incluindo identificação botânica.

d) Confecção de chaves de identificação dos gêneros e descrições morfológicas, ilustrações, análise da distribuição geográfica global e da variabilidade morfológica das espécies comercializadas em Diamantina (MG).

\section{Resultados}

O levantamento das espécies comercializadas como "sempre-vivas" levou à detecção de dois pólos principais de comercialização. O primeiro, mais importante, localiza-se em Diamantina para onde converge toda a produção originada de várias localidades do Estado e de algumas serras da Bahia. As espécies comercializadas nesse centro encontram-se relacionadas nas tabelas 1, 2 e 3 . São apresentados, ainda, uma chave para a identificação das famílias e gêneros dessas "sempre-vivas", descrições, ilustrações, dados de distribuição geográfica, variabilidade e fenologia das espécies de Poaceae, Rapateaceae, Cyperaceae, Xyridaceae e de várias espécies de Eriocaulaceae, representando a diversidade morfológica encontrada em cada família. Devido aos problemas taxonômicos existentes em Eriocaulaceae, foram selecionadas para descrição e ilustração algumas espécies bem definidas ou com maior expressividade no contexto do trabalho. As demais espécies apresentam-se listadas ao final das descrições de Eriocaulaceae, acompanhadas pelo material examinado para a identificação.

Outro centro de revenda, pouco expressivo em relação a Diamantina, está em Brasília e concentra especialmente a produção dos campos da Chapada dos Veadeiros, Cristalina e áreas de cerrado de Goiás. As espécies de "sempre-vivas" comercializadas nessa região apresentam-se listadas na Tabela 4, acompanhadas pelo material examinado para a identificação. 


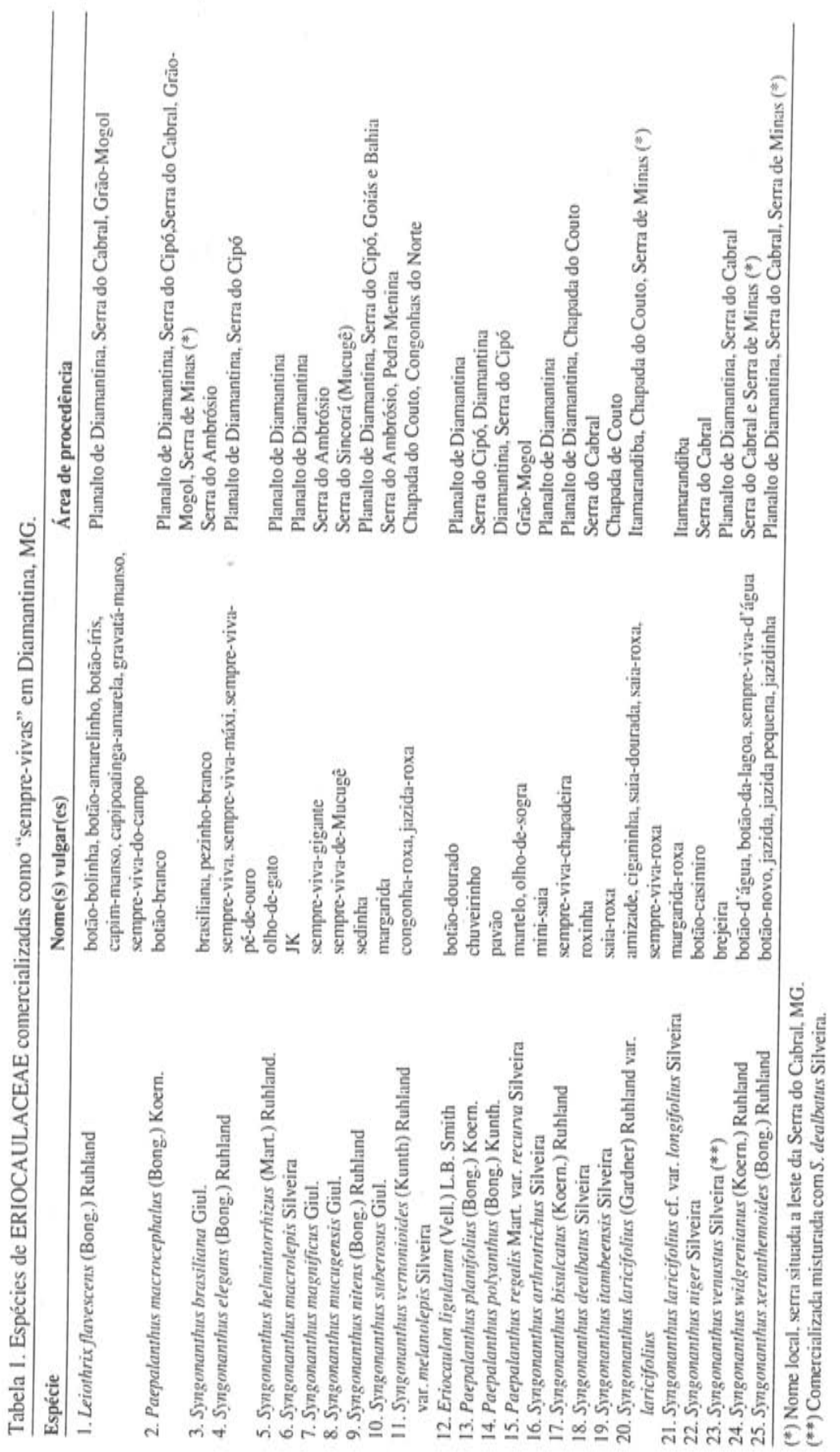




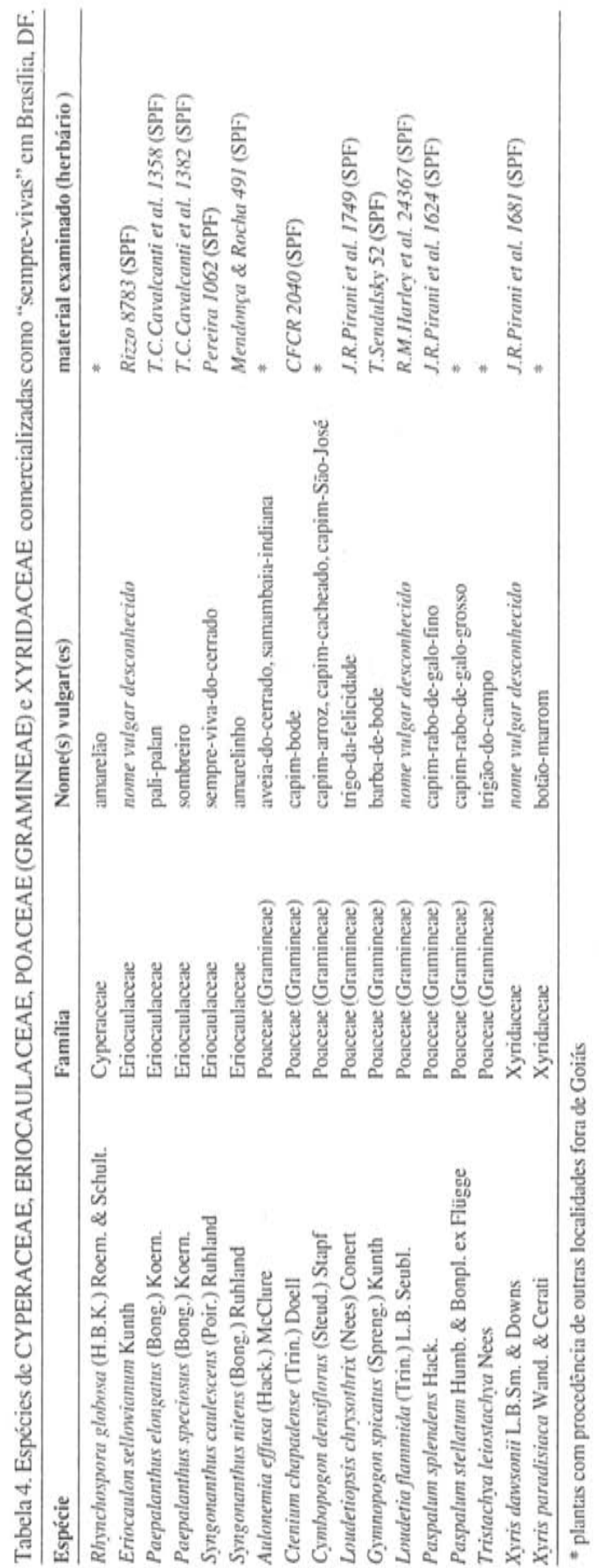


Chave para as famílias e gêneros de "sempre-vivas" comercializadas em Diamantina (MG)

1. Flores diclamídeas, reunidas em capítulos, espigas estrobiliformes ou grupos de espigas congestas, nunca em espiguetas

2. Escapo envolvido na base por uma espata (bráctea estéril da mesma cor do escapo); flores inconspícuas, geralmente alvas; inflorescência do tipo capítulo ....... ERIOCAULACEAE

3. Estames 6 Eriocaulon

3. Estames 3

4. Pétalas das flores pistiladas unidas na região mediana. Brácteas involucrais das séries mais internas maiores ou menores que a altura das flores

Syngonanthus

4. Pétalas das flores pistiladas livres entre si. Brácteas involucrais com a mesma altura das flores

5. Capítulos alvos; estiletes e apêndices do gineceu livres desde a base, anteras dorsifixas.

Paepalanthus

5. Capítulos castanho-claros; estiletes e apêndices do gineceu unidos até acima do meio do comprimento destas estruturas, anteras basifixas

Leiothrix

2. Escapo não envolvido por espata; flores conspícuas, amarelas; inflorescência do tipo espiga

6. Inflorescência globosa formada por um conjunto de espigas congestas, protegido por duas brácteas estéreis na base, espatáceas e muito longas

RAPATEACEAE - Cephalostemon

6. Espigas isoladas, estrobiliformes, duas brácteas basais curtas, quando longas, numerosas XYRIDACEAE-XYris

1. Flores aclamídeas ou com perigônio rudimentar, reunidas em espiguetas dispostas em inflorescências capituliformes ou panículas

7. Folhas com bainha fechada, sem lígula; espiguetas cilíndricas com as glumas espiraladas, reunidas em inflorescências capituliformes protegidas por brácteas estéreis

CYPERACEAE - Rhynchospora

7. Folhas com bainha aberta, liguladas; espiguetas aplanadas com os antécios de disposição dística, reunidas em panículas sem proteção de brácteas estéreis

POACEAE (GRAMINEAE)

8. Lâminas foliares pecioladas Aulonemia

8. Lâminas foliares não pecioladas.

9. Lema com arista tripartida Aristida

9. Lema mútico ou com arista simples

10. Articulação entre ráquila e pedicelo das espiguetas localizada acima das glumas, de modo que estas persistem na inflorescência após a queda dos antécios 
11. Plantas dióicas, 3-10m alt., inflorescências 1-3m compr. Espiguetas pistiladas com pilosidade densa e branca Gynerium

11. Plantas hermafroditas, $0,5-1,5 \mathrm{~m}$ alt., inflorescências $0,15-0,30 \mathrm{~m}$ compr. Espiguetas com pilosidade dourada Loudetiopsis

10. Articulação entre ráquila e pedicelo das espiguetas localizada abaixo das glumas, de modo que estas caem da inflorescência juntamente com os antécios maduros

12. Espiguetas isoladas, constituindo a unidade de dispersão. Antécio II coriáceo, mais consistente do que as glumas membranáceas.

13. Panícula espiciforme, cilíndrica, com cerdas persistentes na base da espigueta. Gluma I presente Setaria

13. Panícula de ramos unilaterais espiciformes, sem cerdas. Gluma I ausente Axonopus

12. Espiguetas em pares sobre cada nó da ráquis, uma séssil e uma pedicelada, constituindo a unidade de dispersão juntamente com um artículo da ráquis. Antécios hialinos, menos consistentes do que as glumas coriáceas ou coriáceo-membranáceas

14. Racemos reunidos em panícula corimbosa, cada racemo protegido por uma espatéola. Lema II da espigueta séssil profundamente bífido, com arista de 7 a $10 \mathrm{~mm}$ compr.

Schizachyrium

14. Dois ou mais racemos por espatéola, digitados no ápice do colmo florífero ou reunidos em panículas não corimbosas. Lema II da espigueta séssil de ápice inteiro, mútico ou com arista de $8 \mathrm{~mm}$ compr. Espigueta pedicelada rudimentar, 0,51,5mm compr., ou desenvolvida, 3-4mm compr.

15. Espigueta pedicelada rudimentar, neutra. Panícula plumosa, tricomas longos (ca. 2 vezes mais longos do que a espigueta séssil) sobre a ráquis e os pedicelos

Andropogon

15. Espigueta pedicelada desenvolvida, neutra ou estaminada. Panícula não plumosa, pedicelos e ráquis glabros ou com tricomas curtos (menores do que a espigueta séssil)

16. Panícula aberta, ráquis e pedicelos glabros. Glumas coriáceas Sorghum

16. Panícula contraída, ráquis e pedicelos com tricomas curtos. Glumas coriáceo-membranosas 
Descrição e comentários das espécies comercializadas em Diamantina (MG)

\section{ERIOCAULACEAE}

1. Leiothrix flavescens (Bong.) Ruhland in Engler, Pflanzenr. 4(30): 231.1903. Figuras 2-4.

Nomes vulgares: botão-bolinha, botão-amarelinho (segundo os habitantes de Diamantina, MG), botão-íris (segundo a empresa BRASITIMEX), capim-manso, capipoatinga-amarela, gravatá-manso, sempre-viva-do-campo (Moldenke 1977).

Erva com caule curto portando folhas em roseta basal de onde partem os escapos terminais. Folhas planas a raramente conduplicadas, $25 \times 0,3-1,5 \mathrm{~cm}$, lanceoladas a ligeiramente falcadas, membranáceas a cartáceas, geralmente pubescentes em ambas as faces. Espatas 5-18cm compr., pubescentes, ápice truncado. Escapos $30-70 \mathrm{~cm}$ compr., pubescentes. Capítulos 8-12mm diâm. Brácteas involucrais dispostas em 4-5 séries, oblongo-ovais, ápices agudos, pilosas na face abaxial. Brácteas florais oblongo-espatuladas, ápices agudos, do mesmo tamanho ou menores que as flores, pilosas na face abaxial. Flores estaminadas sésseis, ca. $4 \mathrm{~mm}$ compr., duas sépalas dorsais carenadas e uma sépala posterior plana, pilosas na face abaxial; corola tubulosa; estames 3 , filetes cilíndricos e livres desde a base, anteras basifixas. Flores pistiladas sésseis, ca. $4 \mathrm{~mm}$ compr.; sépalas livres entre si, carenadas, pilosas na face abaxial; pétalas livres entre si, planas, ápices obtusos a agudos, pouco ciliadas no ápice; estiletes e apêndices unidos até o meio ou mais acima, estiletes cilíndricos, estigmas simples.

Material examinado: MINAS GERAIS: Couto Magalhães, Chapada do Couto, A.M.Giulietti et al., CFCR 4680, 17/VII/1984 (K, SPF, SP); Milho Verde, estrada para Serro, N.Hensold et al., CFCR 3740, 22/II/1982 (SPF, MICH).

Esta espécie apresenta a mais ampla distribuição geográfica do gênero, ocorrendo em solos arenosos dos campos de altitude do Peru, Venezuela, Guianas e Brasil. É relativamente freqüente na Bahia, principalmente na Chapada Diamantina, sendo mais rara nas restingas litorâneas. É mais abundante na Cadeia do Espinhaço, em Minas Gerais, passando a ter populações com menos indivíduos nas Serra do Mar e Mantiqueira (Rio de Janeiro e São Paulo), chegando até o Paraná, Santa Catarina e Rio Grande do Sul (Giulietti 1984).

Na região de Diamantina, floresce especialmente entre os meses de abril e maio e sua comercialização pode estar mais relacionada à facilidade de coleta do que à beleza do capítulo de cor castanha e com brácteas relativamente curtas.

2. Paepalanthus macrocephalus (Bong.) Koern., Fl. bras. 3(1): 379. 1863.

Figura 5. 
Nome vulgar: botão-branco.

Erva com caule curto ou ramificado com ramos muito curtos, de onde partem folhas em roseta basal com escapos terminais. Folhas 3-5,5 X 0,4-0,7cm, lanceoladas, ápice agudo, glabras. Espatas ca. 6,5cm compr., glabras, ápice agudo. Escapos 40$55 \mathrm{~cm}$ compr., pubescentes, indumento prateado. Capítulos ca. $1,5 \mathrm{~cm}$ diâm. Brácteas involucrais dispostas em 6-7 séries, oval-lanceoladas, castanhas, pilosas na face abaxial. Brácteas florais oblongo-espatuladas, menores que as flores, pilosas na face abaxial. Flores estaminadas e pistiladas sésseis, distribuídas em séries alternadas no capítulo. Flores estaminadas ca. $4 \mathrm{~mm}$ compr.; sépalas unidas na base, pilosas na face abaxial; antóforo ca. $3 \mathrm{~mm}$ compr.; corola tubulosa, menor que as sépalas, glabra; estames unidos ao antóforo, filetes cilíndricos e livres desde a base, anteras dorsifixas. Flores pistiladas ca. $3 \mathrm{~mm}$ compr.; sépalas livres entre si, quase do mesmo tamanho das pétalas, pilosas na face abaxial; pétalas livres entre si, densamente ciliadas no ápice; estiletes cilíndricos, estigmas bífidos.

Material examinado: MINAS GERAIS: Diamantina, estrada Diamantina-Biribiri, E.M.Isejima et al., CFCR 5539, 15/X/1984 (SPF); Santana do Riacho, Serra do Cipó, rodovia Belo Horizonte-Conceição do Mato Dentro, km 116, A.B.Joly et al., CFSC 164, 6/VI/1970 (SPF); km 120, A.B.Joly et al., CFSC 4515, 18/X/1973 (SPF); Fechados, ca. 5 km do Rio Preto, N.Hensold et al., CFCR 578, 22/III/1982 (SPF).

A espécie é bastante comum nos campos arenosos de Minas Gerais, especialmente na Serra do Cipó, Serra do Cabral e Diamantina. É facilmente distinta das demais Eriocaulaceae comercializadas como "sempre-vivas" pelos seus capítulos alvos e escapos rígidos de até $50 \mathrm{~cm}$ de comprimento e indumento prateado. O grande volume de venda da espécie, ca. $10.000 \mathrm{~kg}$ (Giulietti et al. 1988), está provavelmente bastante relacionado a sua alta freqüência na área de Diamantina.

3. Syngonanthus brasiliana Giul., Bolm. Botânica Univ. São Paulo 15: 63-65. Figuras 1-12. 1996.

Figuras 1,8 .

Nomes vulgares: brasiliana, pezinho-branco.

Erva com caule curto portando folhas em roseta basal de onde partem 8-12 escapos teminais. Folhas eretas, $4-7$ X $0,1-0,15 \mathrm{~cm}$, lineares, base ampliada com 5$6 \mathrm{~mm}$ larg., densamente pilosas, tricomas alvos. Espatas $4-5 \mathrm{~cm}$ compr., densamente pilosas, tricomas alvos e longos, ápice oblíquo. Escapos 30-40cm compr., pilosos, tricomas longos e alvos. Capítulos 0,8-1 cm diâm. Brácteas involucrais dispostas em 5 séries, ultrapassando a altura das flores, ovais, passando nas séries mais internas a oval-oblongas, espatuladas até linear-espatuladas, ápice arredondado, castanhas passando a alvas nas séries mais internas, glabrescentes na face abaxial. Flores estaminadas ca. $6 \mathrm{~mm}$ compr., pediceladas; sépalas unidas na base, ápices obtusos; pétalas 
unidas na base, um pouco menores que as sépalas, glabras, com estruturas glandulares dilatadas no ápice e adnatas às pétalas; filetes cilíndricos e livres desde a base; anteras dorsifixas. Flores pistiladas ca. $5 \mathrm{~mm}$ compr., pediceladas; sépalas livres entre si, carenadas, glabras; pétalas unidas na região mediana, carenadas, glabras; estiletes e apêndices unidos na região mediana, estigmas simples.

Material examinado: MINAS GERAIS: Rio Vermelho, Pedra Menina, Serra do Ambrósio, A.M.Giulietti et al., CFCR 4460, 14/VII/1984 (holótipo: SPF).

A espécie é considerada endêmica da Serra do Ambrósio. Nesta Serra, é restrita às cotas mais baixas do morro, até $1000 \mathrm{~m}$, estando ausente a partir desta altitude, substituída, por Syngonanthus magnificus ou por Syngonanthus suberosus. São plantas perenes, formando densas populações de plântulas no período entre abril e maio e aparecendo de forma isolada e esparsa, especialmente em julho.

S. brasiliana já foi bastante comercializada, entretanto a quantidade coletada atualmente tem sido muito pequena, levando a crer que seja uma espécie com grande risco de extinção.

4. Syngonanthus elegans (Bong.) Ruhland in Engler, Pflanzenr. 4 (30): 275. 1903. Figuras 1, 17-20.

Nomes vulgares: sempre-vivas, sempre-viva-maxi, sempre-viva-pé-de-ouro (MG); diamantina (Buenos Aires, Argentina); skyrocket, starflower (Inglaterra); glixie (Viena, Áustria).

Erva com caule curto portando folhas em roseta basal de onde partem 4-60 escapos terminais. Folhas $2,5-13 \times 0,05 \mathrm{~cm}$, estreitamente lineares a cilíndricas, ápice subulado, densamente pilosas; bainhas ampliadas, decíduas e pilosas ou estreitas, persistentes após a queda das folhas, lanosas com tricomas castanho-avermelhados. Espatas 2,5-8cm compr., ciliadas e densamente pilosas, ápices longamente acuminados. Escapos 13-45cm compr., castanhos a castanho-avermelhados, pilosos. Capítulos $0,7-1 \mathrm{~cm}$ diâm. Brácteas involucrais dispostas em ca. 10 séries; as 5 séries mais externas obovais, ápices arredondados, castanho-claras, glabras; as 5 séries mais internas ultrapassando as flores em ca. $3 \mathrm{~mm}$, unguiculadas, ápices obtusos a arredondados, alvas, glabras. Flores estaminadas $3,5-4 \mathrm{~mm}$ compr., pediceladas; sépalas unidas até a metade, elípticas, hialinas, glabras; pétalas unidas até a metade, elípticas, hialinas, glabras; filetes aplanados e livres desde a base com a região basal ampliada, anteras dorsifixas. Flores pistiladas 3-3,5mm compr., pediceladas; sépalas livres entre si, elípticas, hialinas, glabras; pétalas unidas na região mediana, estreitamente espatuladas, maiores que as sépalas, hialinas, ciliadas e pouco pilosas na face abaxial; gineceu estipitado; estiletes e apêndices unidos na região basal; estiletes livres entre si e aplanados, estigmas simples.

Material examinado: MINAS GERAIS: Diamantina, margem da estrada Corinto- 
Conselheiro Mata, A.M.Giulietti 922-80, CFCR 10, 3/IV/1980 (SPF); Diamantina, margem da estrada Diamantina-Belo Horizonte, km 65, A.M.Giulietti 970-80, CFCR 58,4/IV/1980 (SPF); Diamantina, em campo de cultivo de Eriocaulaceae, A.M. Giulietti 991-80, CFCR 79, 5/IV/1980 (SPF); Diamantina, estrada para Biribiri, $3098 \mathrm{~m}$ alt., N.Hensold et al., CFCR 3168, 8/IV/1982 (SPF); Gouveia, margem da estrada Curvelo-Diamantina, km 66, Serra do Barro Preto, E.M.Isejima et al., CFCR 3572, 9/IV/ 1982 (SPF); Diamantina, A.M.Giulietti, CFCR 3789, 18/V/1984; Couto Magalhães, Chapada do Couto, A.M. Giulietti et al., CFCR 4681, 17/VII/1984 (SPF); Diamantina, estrada para Extração, ca. 7 km de Diamantina, E.M.Isejima et al., CFCR 5636, 16/X/ 1984 (SPF); Diamantina, N.L.Menezes et al., CFCR 7800, 5/IV/1985 (SPF).

Espécie bastante freqüente na região de Diamantina e facilmente distinta das demais espécies de "sempre-vivas" pela forma e pilosidade das folhas e, especialmente, pelo tamanho relativamente grande dos capítulos e grande número de escapos por planta. As plantas que apresentam folhas cilíndricas, bainhas estreitas e persistentes no caule com tricomas castanho-avermelhados estão incluídos em Syngonanthus elegans var. elegans, enquanto as que apresentam folhas estreitamente lineares, bainhas ampliadas e decíduas com tricomas alvos incluem-se em Syngonanthus elegans var. elanatus. Pela beleza de seus capítulos, esta espécie é a sempre-viva mais exportada da região. Em 1984 contribuiu com parte significativa da produção total de "semprevivas" para exportação com os mais altos preços de venda (Giulietti et al. 1988),

Os primeiros cultivos e manejos racionais em "sempre-vivas" foram realizados com esta espécie em duas áreas próximas a Diamantina, onde também ocorrem espontaneamente.

\section{Syngonanthus helminthorrhizus (Mart.) Ruhland in Engler, Pflanzenr. 4(30): 261 .
1903.}

Nome vulgar: olho-de-gato.

Ervas com rizoma portando folhas em roseta basal de onde parte um caule aéreo com um verticilo apical de folhas e 9-11 escapos terminais. Folhas das rosetas basais 6-11 X 0,1cm, lineares, ápice acuminado, densamente pilosas em ambas as faces, tricomas capitados. Caules aéreos sem folhas, densamente pilosos, tricomas filamentosos. Folhas do verticilo eretas, $1-5$ X 0,05-0,1 cm, lineares, mesma pilosidade das folhas basais. Espatas 5-8cm compr., mesma pilosidade das folhas, ápices longamente acuminados. Escapos rígidos, 24-32 cm compr., mesma pilosidade das folhas. Capítulos 1,5-1,7cm diâm. Brácteas involucrais dispostas em ca. 6 séries, estreitamente ovais passando a estreitamente oblongas nas séries mais internas, ápices acuminados, pilosas nas faces abaxiais, tricomas capitados. Flores estaminadas e pistiladas ca. $5,5 \mathrm{~mm}$ compr., pediceladas. Flores estaminadas com sépalas unidas até a metade, elípticas, hialinas, pilosas na região centro-apical de ambas as faces; antóforo ca. $1 \mathrm{~mm}$ compr.; corola tubulosa, glabra, hialina; filetes aplanados e livres desde a base, anteras dorsifixas. Flores pistiladas com sépalas livres entre si, elípticas, hialinas, mesma pilosi- 
dade das sépalas das flores estaminadas; pétalas unidas na região mediana, menores que as sépalas, hialinas; estiletes livres desde a base e aplanados, estigmas simples.

Material examinado: MINAS GERAIS: Datas, Morro do Coco, $3 \mathrm{~km}$ da cidade em direção a Diamantina, 1200-1300 m, R.Mello-Silva et al., CFCR 7995, 4/VIII/1985 (SPF).

A espécie apresenta ampla distribuição geográfica, tendo sido referida por Ruhland (1903) para Minas Gerais, Goiás, São Paulo e Rio Grande do Sul.

É freqüente na região de Datas (MG) em brejos próximos a matas ciliares, entre gramíneas. É facilmente distinta de outras espécies exportadas pelos caules aéreos longos e pelas folhas lineares e longas.

Segundo informações da empresa Silva Flores, da região de Datas, esta espécie foi comercializada há alguns anos, porém a exportação foi abandonada devido à pequena quantidade obtida.

6. Syngonanthus macrolepis Silveira, Fl. serr. Min. p. 72-73, tab. 28. 1908. Figura 9.

Nome vulgar: J.K.

Ervas com rizoma alongado portando folhas em roseta basal de onde parte o caule aéreo folhoso com um verticilo apical de folhas com 1-6 escapos terminais. Folhas das rosetas basais $2-5 \times 0,3-0,4 \mathrm{~cm}$, oblongas, ápice obtuso a agudo, ciliadas e pouco pilosas em ambas as faces. Caules aéreos pilosos, portando 2-4 folhas linear-lanceoladas. Folhas do verticilo eretas, linear-lanceoladas, 2,5-7 X 0,2cm, mesma pilosidade das folhas basais. Espatas laxas, 6-9cm compr., ciliadas no ápice e densamente pilosas, ápice acuminado. Escapos rígidos, 30-45cm compr., densamente pilosos. Capítulos 1,2-1,5cm diâm. Brácteas involucrais dispostas em ca. 6 séries, ultrapassando a altura das flores em ca. $1 \mathrm{~mm}$, elipticas com ápices obtusos nas séries mais externas passando a obovais com ápices agudos ou mucronados nas séries mais internas, creme a douradas com região central mais escura, ciliadas e pilosas nas faces abaxiais. Brácteas florais lineares a obovais, ápices longamente acuminados, pilosas na região central de ambas as faces. Flores estaminadas e pistiladas 5-5,5mm compr., pediceladas. Flores estaminadas com sépalas livres, elípticas a obovais, hialinas, mesma pilosidade das brácteas florais; antóforo ca. $0,5 \mathrm{~mm}$ compr.; corola tubulosa hialina, glabra; filetes aplanados e adnatos às pétalas até a metade do tubo, anteras dorsifixas. Flores pistiladas com sépalas livres, elípticas, hialinas, ciliadas e pilosas na região central das faces abaxiais e ventrais, anel de tricomas entre as sépalas e pétalas; pétalas unidas na região mediana, elípticas, menores que as sépalas, hialinas, pilosas nas faces abaxiais; estiletes e apêndices unidos na região basal, estiletes aplanados, estigmas simples.

Material examinado: MINAS GERAIS: Datas, Morro do Coco, $3 \mathrm{~km}$ da cidade em direção a Diamantina, 1200-1300 m., J.R.Pirani et al., CFCR 7984, 4/VIII/1985 
(SPF).

Espécie característica pelo tamanho de seus escapos e capítulos e pela presença de um caule aéreo folhoso e de brácteas florais. Observou-se que quando ocorre em solos mais arenosos, apresenta brácteas involucrais mais douradas. A espécie apresenta distribuição restrita, ocorrendo apenas nos campos rupestres da Cadeia do Espinhaço de Minas Gerais. Em Diamantina é pouco freqüente, vivendo em solos brejosos, juntamente com outras espécies de "sempre-vivas", como Leiothrix flavescens, Paepalanthus macrocephalus, Cephalostemom ridelianus e Rhynchospora speciosa.

Segundo informações da empresa Silva Flores, da região de Datas, seu nome vulgar se refere ao primeiro exportador da espécie na região de Curvelo, que era amigo de Juscelino Kubitschek de Oliveira. Foi comercializada há cerca de 8 anos, porém sem muito sucesso devido especialmente à pequena quantidade disponível na região e por ser menos atraente que as demais "sempre-vivas".

7. Syngonanthus magnificus Giul., Bolm. Botânica Univ. São Paulo 15: 67-69. Figuras 26-38. 1996.

Figuras 1, 14-15.

Nome vulgar: sempre-viva-gigante.

Erva, caule hipógeo e ereto com $2-5 \times 2,5 \mathrm{~cm}$ portando folhas em roseta basal de onde partem 8-15 escapos terminais. Folhas 4-7 X 1,5-3cm, lanceoladas, coriáceas, multinervadas, ciliadas, tricomas malpiguiáceos e alvos. Espatas $6,5-7 \mathrm{~cm}$ compr., pilosas na face abaxial, tricomas malpiguiáceos, pouco pilosas na face adaxial, ápice oblíquo, geralmente denteado, membranáceo. Escapos $20-40 \mathrm{~cm}$ compr. e torcidos com 7 costelas, pilosos, tricomas malpiguiáceos e alvos. Capítulos, 1,5$2 \mathrm{~cm}$ diâm. Brácteas involucrais dispostas em 9-10 séries, ultrapassando muito a altura das flores, ovais com ápices arredondados, castanho-claras e pilosas na face abaxial passando nas séries mais internas a obovais ou oboval-oblongas com ápices obtusos a arredondados, alvas a nacaradas e glabras. Flores estaminadas ca. $2,5 \mathrm{~cm}$ compr., pediceladas; sépalas unidas na base, ápices agudos, glabras; pétalas unidas na base, pouco menores que as sépalas, ápices obtusos, glabras; filetes livres desde a base e cilíndricos, anteras dorsifixas. Flores pistiladas ca. $4 \mathrm{~mm}$ compr., pediceladas; sépalas livres entre si, carenadas, glabras; pétalas unidas na região mediana, de tamanho igual ou pouco maiores que as sépalas; estiletes e apêndices unidos na região basal, estigmas simples.

Material examinado: MINAS GERAIS: Rio Vermelho, Pedra Menina, Serra do Ambrósio, E.M.Isejima et al., CFCR 5513, 14/X/1984 (holótipo: SPF, isótipo: K).

Esta espécie é considerada endêmica da Serra do Ambrósio (MG). É perene, devido ao seu caule subterrâneo desenvolvido, semelhante ao apresentado por $S$. suberosus. A época de floração e de coleta é de junho a agosto, apresentando, porém, 
flores em antese até outubro. É bem caracterizada pelos escapos longos e rígidos e pelos capítulos grandes com brácteas involucrais de aspecto nacarado. Segundo Giulietti et al. (1988) é a espécie que apresenta o maior preço de venda em Diamantina, porém, com pouca quantidade exportada.

8. Syngonanthus mucugensis Giul., Bolm. Botânica Univ. São Paulo 15: 69-71. Figuras 39-51. 1996.

Figuras 1, 6-7.

Nome vulgar: sempre-viva-de-mucugê.

Erva com caule curto portando folhas em roseta basal de onde partem 10-14 escapos terminais. Folhas 3-5,5 X 0,2-0,3cm, lanceoladas, base ampliada com 0,5$0,6 \mathrm{~cm}$ larg., coriáceas, multinervadas, pilosas e densamente ciliadas a glabrescentes, tricomas malpiguiáceos e alvos. Espatas 4,5-7,5cm compr., pilosas na face abaxial, tricomas malpiguiáceos, ápice oblíquo, tridenteado. Escapos $30-50 \mathrm{~cm}$ compr. e torcidos com 5 costelas, pilosos, tricomas malpiguiáceos. Capítulos $1,5-2 \mathrm{~cm}$ diâm. Brácteas involucrais dispostas em 5-7 séries, ultrapassando a altura das flores, ovallanceoladas com ápice agudo, castanho-claras, pilosas na face abaxial, passando nas séries mais internas a obovais ou oboval-oblongas com ápice obtuso a arredondado, creme, glabras. Flores estaminadas ca. $6 \mathrm{~mm}$ compr., pediceladas; sépalas unidas na base; pétalas unidas até acima do meio, pouco maiores que as sépalas, glabras; filetes livres desde a base e cilíndricos, anteras dorsifixas, Flores pistiladas ca. $5 \mathrm{~mm}$ compr., pediceladas; sépalas livres entre si, carenadas, glabras; pétalas unidas na região mediana, maiores que as sépalas, carenadas, ápices obtusos, glabras; estiletes e apêndices unidos na região basal, estigmas simples, inclusos.

Material examinado: BAHIA: Mucugê, Alto do Morro do Pina, estrada MucugêGuiné, a $25 \mathrm{~km}$ NW de Mucugê, A.M.Giulietti et al., CFCR 1554, 20/VII/1981 (holótipo: SPF, isótipo: K); $3 \mathrm{~km} \mathrm{SW}$ de Mucugê na estrada para Cascavel, Serra do Sincorá, R.M.Harley et al. 21043, 27/III/1980 (parátipos: CEPEC, K, SPF); margem da estrada Mucugê-Cascavel km 3-6, próx. do Rio Paraguaçu, N.L.Menezes et al., CFCR 1459, 20/VII/1981 (parátipos: K, SPF); Mucugê, Serra de São Pedro, A. M. Giulietti et al., CFCR 7054, 17/XII/1984 (parátipos: K, SPF).

Ocorre em Mucugê (BA) sendo restrita ao alto das montanhas que rodeiam a cidade, em altitudes entre 1100-1280 m. É planta perene, com sistema subterrâneo pouco desenvolvido.

A emissão de escapos se inicia em março, e os capítulos estão totalmente desenvolvidos e com flores em antese desde julho até agosto. Em dezembro, as plantas se encontram estéreis ou com poucos escapos velhos e com frutos sem sementes.

A espécie se caracteriza por seus longos e rígidos escapos e pelos grandes capítulos radiados, sendo a espécie de sempre-viva mais exportada em Mucugê e uma das mais caras, juntamente com $S$. magnificus e $S$. suberosus. 
A época de colheita se dá no mês de julho, sendo muito comum encontrar, em toda a cidade, escapos com capítulos secando ao sol. Segundo informações dos habitantes locais, o material coletado destina-se exclusivamente à exportação. Apesar disso, pequenas quantidades puderam ser encontradas em depósitos de revenda de Diamantina e Serra do Cabral.

9. Syngonanthus nitens (Bong.) Ruhland, in Engler, Pflanzenr. 4 (30): 254. 1903. Figura 10.

Nome vulgar: sedinha.

Erva com caule curto portando folhas em roseta basal de onde partem 3-10 escapos terminais. Folhas $1-4$ X 0,1-0,2cm, lineares a oblongas, ápice acuminado, ciliadas e pouco pilosas em ambas as faces ou somente nas faces adaxiais ou glabras. Espatas 2,5-5cm compr., ciliadas e densamente pilosas, ápices longamente acuminados. Escapos 13-40cm compr., dourados, glabros ou com poucos tricomas entre as costelas. Capítulos 6-8mm diâm. Brácteas involucrais dispostas em 5-6 séries, não ultrapassando a altura das flores, oblongas passando a obovais nas séries mais internas, ápices obtusos a arredondados, creme, glabras. Flores estaminadas e pistiladas $3-4 \mathrm{~mm}$ compr., pediceladas. Flores estaminadas em número reduzido; sépalas unidas na base ou até a metade, elípticas, hialinas, pilosas na região centro-apical de ambas as faces, antóforo ca. $1 \mathrm{~mm}$ compr.; tubo da corola hialino, glabro; filetes aplanados e totalmente adnatos às pétalas, anteras dorsifixas. Flores pistiladas com sépalas livres entre si, elípticas, hialinas, ciliadas e pilosas na região centro-apical de ambas as faces; anel piloso entre sépalas e pétalas; pétalas unidas na região mediana, obovais, menores que as sépalas, glabras; estiletes e apêndices unidos na região basal, estiletes aplanados, estigmas simples.

Material examinado: MINAS GERAIS: Diamantina, estrada para Extração, ca. 7 km de Diamantina, E.M.Isejima et al., CFCR 5632, 16/X/1984 (SPF).

Espécie bastante comum nas serras de toda a Cadeia do Espinhaço, ocorrendo também nos campos de altitude da porção central da América do Sul. Caracteriza-se por apresentar escapos dourados e brácteas involucrais creme e brilhantes.

10. Syngonanthus suberosus Giul., Bolm. Botânica Univ. São Paulo 15: 65-67. Figuras 13-25. 1996.

Figuras 1, 16.

Nome vulgar: margarida.

Erva com caule ereto de até $10 \mathrm{~cm}$ compr., $3 \mathrm{~cm}$ diâm., protegido por grossa cortiça, portando folhas em roseta basal de onde partem 10-15 escapos. Folhas 7-8 X $3-3,5 \mathrm{~cm}$, lanceoladas, coriáceas, multinervadas, ciliadas. Espatas $7,5-8 \mathrm{~cm}$ compr., densamente pilosas, tricomas adpressos e alvos, ápice oblíquo. Escapos 40-50cm, 
pouco pilosos, tricomas adpressos. Capítulo 1,0-1,5cm diâm. Brácteas involucrais dispostas em 5-7 séries, ultrapassando a altura das flores, ovais com ápice arredondado, mais espessadas na parte central, castanho-claras, passando nas séries mais internas a oval-oblongas e espatuladas ou oval-oblongas, creme a alvas. Flores estaminadas ca. $6 \mathrm{~mm}$ compr., pediceladas; sépalas unidas até quase o meio, ápices obtusos; pétalas unidas até o meio, de tamanho igual ou pouco menores que as sépalas, ápices arredondados, glabras; filetes livres desde a base, anteras dorsifixas. Flores pistiladas ca. $3,5 \mathrm{~cm}$ compr., pediceladas; sépalas livres entre si, carenadas, glabras; pétalas unidas na região mediana, carenadas, ápices obtusos, pilosas.

Material examinado: MINAS GERAIS: Rio Vermelho, Pedra Menina, Serra do Ambrósio, A.M.Giulietti et al., CFCR 4463, 14/VII/1984 (holótipo: SPF).

A espécie ocorre somente na Serra do Ambrósio, onde é restrita às áreas de solo arenoso do Morro Espigão do Meio. São plantas perenes, com caule protegido por grossa cortiça, daí o epíteto específico. Além deste caule característico, apresenta folhas e escapos longos, assemelhando-se a S. magnificus. Apesar da semelhança e de ambas ocorrerem na Serra do Ambrósio, estas duas espécies habitam morros diferentes e são distintas quanto às características dos capítulos e brácteas involucrais. S. suberosus é comercializada pelo fato de seus escapos serem longos e rígidos e pelos seus capítulos radiados. A floração ocorre no mês de julho, quando os escapos e capítulos atingem dimensões maiores, prolongando-se até novembro. No depósito da empresa Silva Flores (Datas, MG) há informação da ocorrênca da espécie em Itamarandiba (MG). Porém, até o momento, não foi localizada nas serras deste município.

11. Syngonanthus vernonioides (Kunth) Ruhland var. melanolepis Silveira, Floral. mont.1. p. 396. 1928.

Figuras 11-13.

Nomes vulgares: congonha-roxa, jazida-roxa.

Erva com caule curto portando folhas em roseta basal de onde partem 1-2 escapos terminais. Folhas planas a canaliculadas, eretas a flexuosas, $3-22 \times 0,05-0,25 \mathrm{~cm}$, lineares, ápice arredondado e castanho-escuro, pilosas tornando-se posteriormente pilosas somente na nervura central de ambas as faces; bainhas ampliadas envolvendo o caule, ciliadas na região apical e persistentes após a queda das folhas. Espatas $1-8 \mathrm{~cm}$ compr., metade superior hialina e metade inferior castanho-escura, densamente pilosas, ápices longamente acuminados a apiculados. Escapos eretos a flexuosos, $5-46 \mathrm{~cm}$ compr., densamente pilosos. Capítulos $0,5-1 \mathrm{~cm}$ diâm. Brácteas involucrais dispostas em 9-15 séries, menores que a altura das flores em $1-2 \mathrm{~mm}$, obovais com ápices arredondados, as brácteas das duas séries mais internas elípticas com ápices obtusos a arredondados, castanho-escuras a marrons, glabras. Flores estaminadas 5-6,5mm compr., pediceladas.; sépalas unidas no terço inferior, elípticas, hialinas, glabras; antóforo ca. $0,2 \mathrm{~mm}$ compr.; pétalas unidas no terço inferior ou até a metade, elípticas, 
hialinas, glabras; filetes livres desde a base e aplanados, anteras dorsifixas. Flores pistiladas ca. $4 \mathrm{~mm}$ compr., pediceladas; sépalas livres entre si, ovais a elípticas, hialinas, glabras; antóforo ca. $0,2 \mathrm{~mm}$ compr.; pétalas unidas na região mediana, estreitamente espatuladas, maiores que as sépalas, hialinas, densamente ciliadas e pilosas na face abaxial da metade inferior; estiletes e apêndices unidos na região basal; estiletes aplanados, estigmas simples.

Material examinado: MINAS GERAIS: Santana do Riacho, Serra do Cipó, rodovia Belo-Horizonte-Conceição do Mato Dentro: km 143, aproximadamente $7 \mathrm{~km}$ além da bifurcação para Morro do Pilar, Fazenda Capão Redondo, V.L.Scatena, CFSC 11197. 11199, 30/VIII/1988 (SPF).

Este taxon é caracterizado por apresentar folhas estreitas com ápice arredondado, geralmente canaliculadas com pilosidade persistindo na nervura central de ambas as faces e brácteas involucrais castanho-escuras a marrons. Ocorre em algumas serras da Cadeia do Espinhaço, em Minas Gerais.

\section{Eriocaulon ligulatum (Vell.) L.B. Smith}

Nome vulgar: botão-dourado.

Material examinado: MINAS GERAIS: Datas, Morro do Coco, $3 \mathrm{~km}$ da cidade em direção a Diamantina, 1200-1300m,J.R.Pirani et al., CFCR 7996, 4/VIII/1985 (SPF).

\section{Paepalanthus planifolius (Bong.) Koern.}

Nome vulgar: chuveirinho.

Material examinado: MINAS GERAIS: Datas, Morro do Coco, $3 \mathrm{~km}$ da cidade em direção a Diamantina, 1200-1300m, R.Mello-Silva et al., CFCR 8023, 3/VIII/1985 (SPF).

\section{Paepalanthus polyanthus (Bong.) Kunth.}

Nome vulgar: pavão.

Material examinado: MINAS GERAIS: Diamantina, margem da estrada DiamantinaConselheiro Mata, $5 \mathrm{~km}$ de Diamantina, A.M.Giulietti et al., CFCR 1820, 30/VIII/ 1981 (SPF).

\section{Paepalanthus regalis Mart. var. recurva Silveira}

Nomes vulgares: martelo, olho-de-sogra. 
Material examinado: MINAS GERAIS: Grão Mogol, Jambeiro a 7 km de Grão Mogol, T.B.Cavalcanti et al., CFCR 8537, 5/IX/1985 (SPF).

\section{Syngonanthus arthrotrichus Silveira}

Nome vulgar: mini-saia.

Material examinado: MINAS GERAIS: Diamantina, margem da estrada DiamantinaBiribiri-Sentinela, A.M.Giulietti et al., CFCR 4285, 23/III/1984 (SPF).

\section{Syngonanthus bisulcatus (Koern.) Ruhland}

Nome vulgar: sempre-viva-chapadeira.

Material examinado: MINAS GERAIS: Diamantina, estrada Diamantina-Biribiri, 3 km do estádio JK, E.S.Esejima et al., CFCR 5541, 15/X/1984 (SPF).

\section{Syngonanthus dealbatus Silveira}

Nome vulgar: roxinha.

Material examinado: MINAS GERAIS: Joaquim Felício, Serra do Cabral, Faz. da Onça, 1100 m, R.Mello-Silva et al., CFCR 8161, 1/IX/1985 (SPF).

\section{Syngonanthus itambeensis Silveira}

Nome vulgar: saia-roxa.

Material examinado: MINAS GERAIS: Itambé do Serro, A. Silveira 657 (R); N.L. Menezes et al., CFCR 193, 19/VII/1980 (SPF).

20. Syngonanthus laricifolius (Gardner) Ruhland var. laricifolius

Nomes vulgares: amizade, ciganinha, saia-dourada, saia-roxa, sempre-viva-roxa.

Material examinado: MINAS GERAIS: Couto Magalhães. Chapada do Couto, A.M.Giulietti et al., CFCR 4706, 17/VII/1984 (SPF).

21. Syngonanthus laricifolius $\mathrm{cf}$. var. longifolius Silveira

Nome vulgar: margarida-roxa.

Material examinado: MINAS GERAIS: Botumirim, M.G.C. 467, 27/VII/1991 (SPF). 


\section{Syngonanthus niger Silveira}

Nome vulgar: botão-casimiro.

Material examinado: MINAS GERAIS: Joaquim Felício, Serra do Cabral, Faz. da Onça, 1100 m, J.R.Pirani et al., CFCR 8111, 1/IX/1985 (SPF).

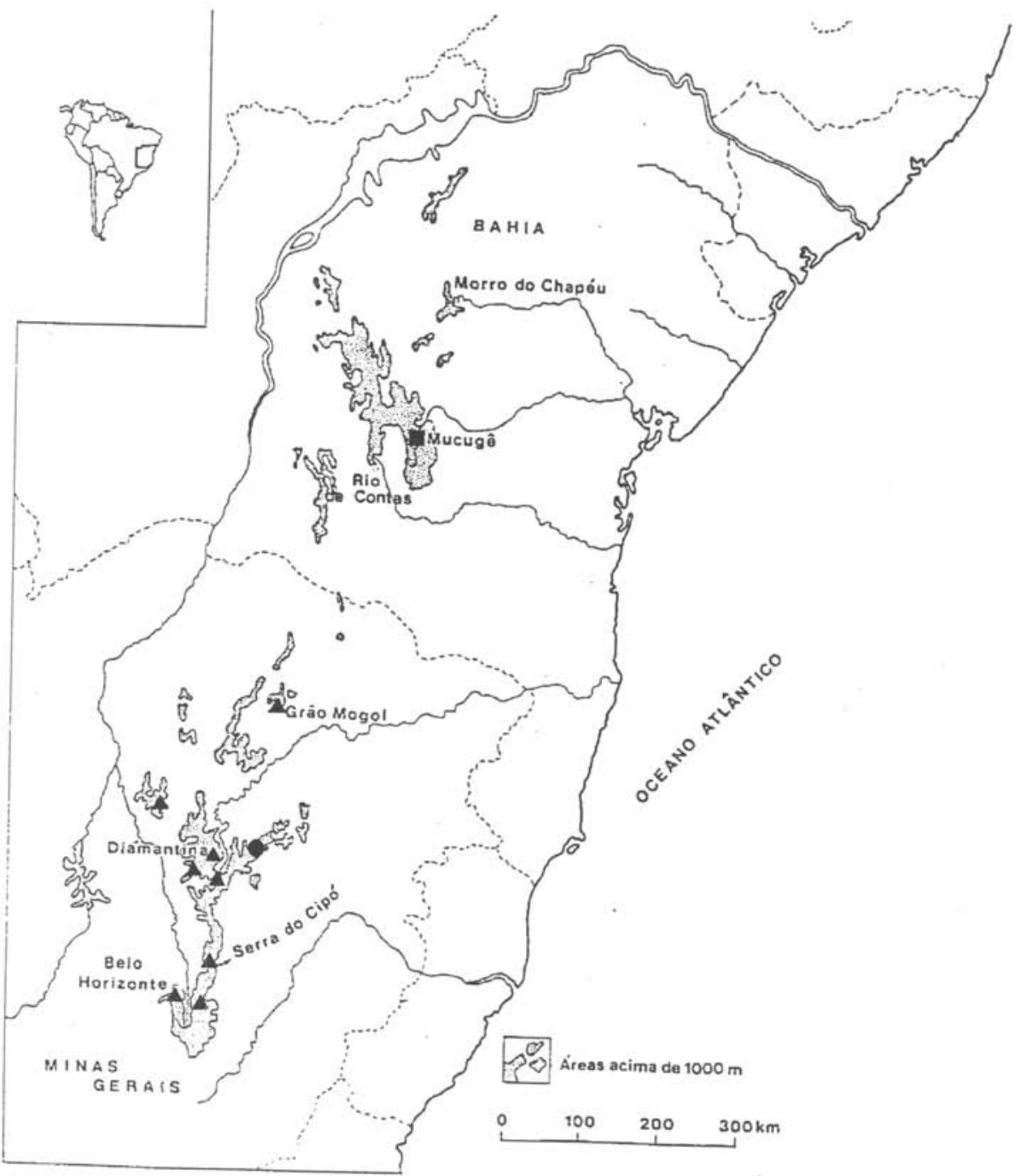

Figura 1. Mapa da Cadeia do Espinhaço, Brasil, mostrando a distribuição geográfica de algumas espécies: Syngonanthus mucugensis $\mathbf{m}$; S. elegans $\mathbf{\Lambda}$; S. brasiliana, S. magnificus, S. suberosus 


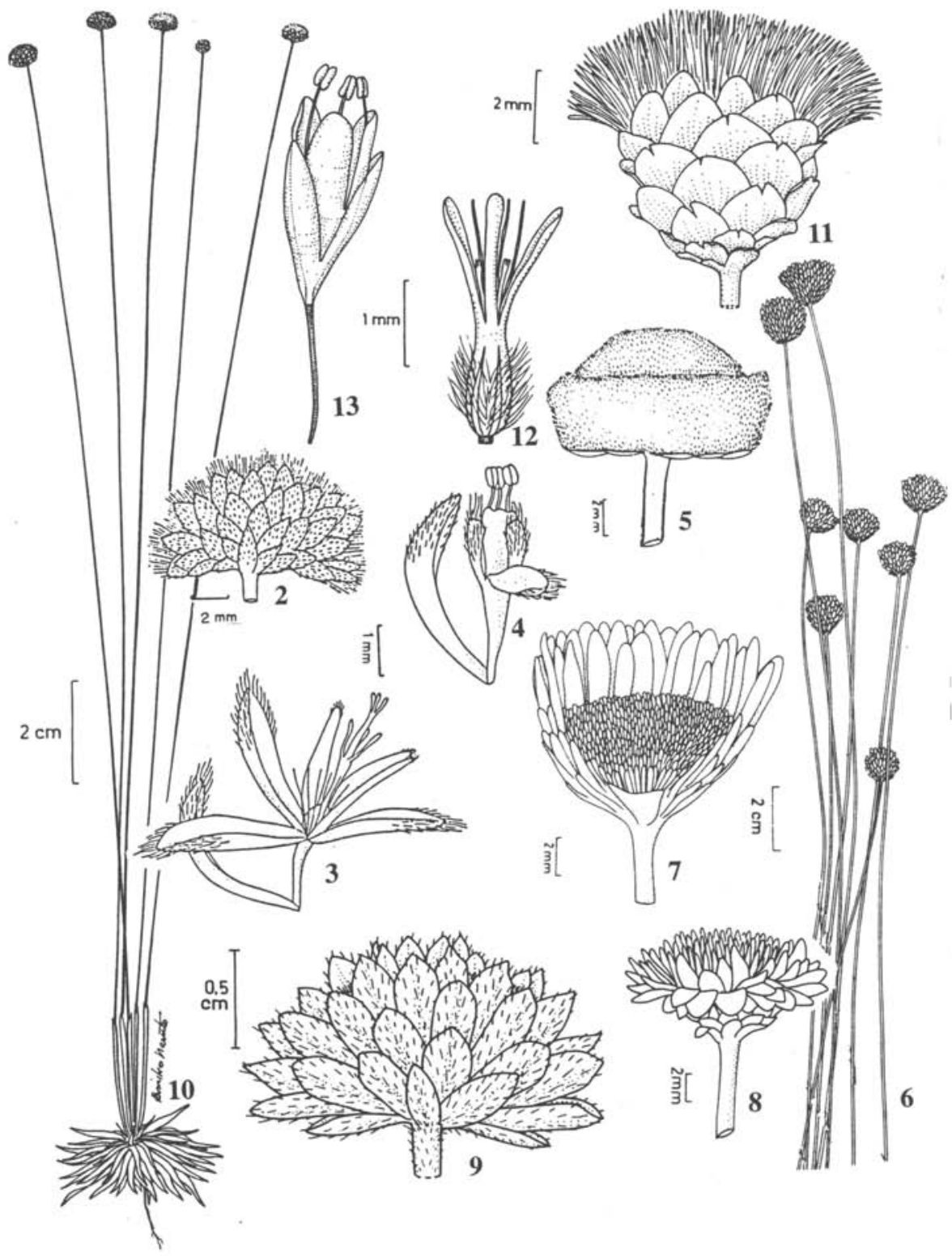

Figura 2-4. Leiothrix flavescens: 2. Capitulo; 3. Flor pistilada; 4. Flor estaminada. Fig 5. Paepalanthus macrocephalus: Capítulo. Fig. 6-7. Syngonanthus mucugensis: 6. Escapos e capítulos; 7. Capítulo. Fig. 8. Syngonanthus brasiliana: Capitulo. Fig. 9. Syngonanthus macrolepis: Capítulo. Fig. 10. Syngonanthus nitens: Hábito. Fig. 11-13. Syngonanthus vernonioides var. melanolepis: 11. Capítulo; 12. Corola da flor pistilada mostrando as pétalas unidas na região mediana; 13. Flor estaminada. 


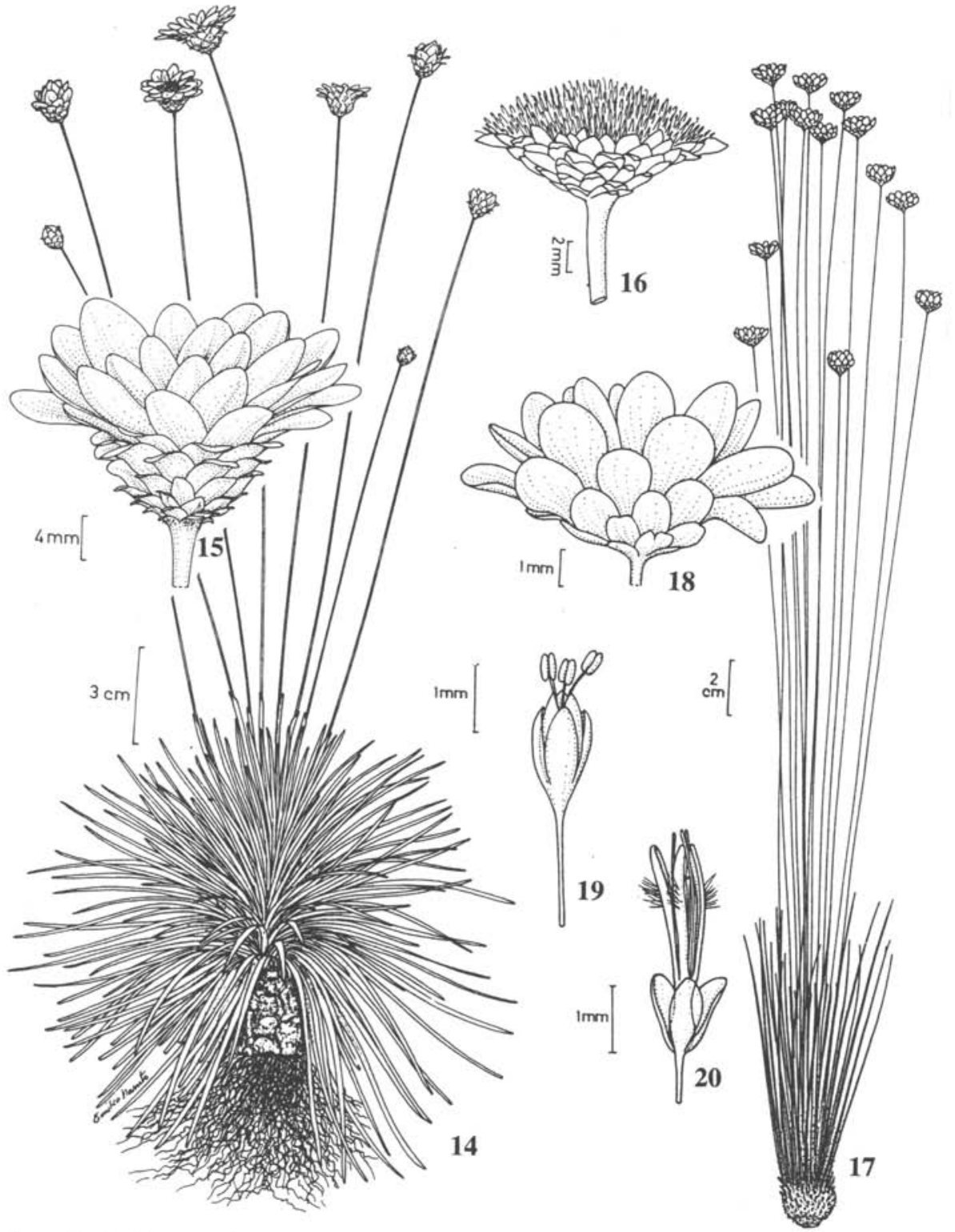

Figura 14-15. Syngonanthus magnificus: 14. Hábito; 15. Capítulo. Fig. 16. Syngonanthus suberosus: Capítulo. Fig. 17-20. Syngonanthus elegans: 17. Hábito; 18. Capítulo; 19. Flor estaminada; 20. Flor pistilada. 


\section{Syngonanthus venustus Silveira}

nome vulgar: brejeira.

Material examinado: MINAS GERAIS: Joaquim Felício, Serra do Cabral, Faz. da Onça, 1100 m, M.L.Kawasaki et al., CFCR 8138, 1/IX/1985 (SPF).

\section{Syngonanthus widgrenianus (Koern.) Ruhland}

Nomes vulgares: botão-d'água, botão-da-lagoa, sempre-viva-d'água.

Material examinado: MINAS GERAIS: Joaquim Felício, Serra do Cabral, Faz. da Onça, 1100 m, M.L.Kawasaki et al., CFCR 8160, 1/IX/1985 (SPF).

\section{Syngonanthus xeranthemoides (Bong.) Ruhland}

Nomes vulgares: botão-novo, jazida, jazida pequena, jazidinha.

Material examinado: MINAS GERAIS: Joaquim Felício, Serra do Cabral, Faz. da Onça, $1100 \mathrm{~m}$, D.C.Zappi et al., CFCR 8115, 1/IX/1985 (SPF).

\section{POACEAE (GRAMINEAE)}

1. Andropogon leucostachyus H.B.K., Nov. Gen. Sp. Pl. 1: 187.1816.

Figuras 21-23.

Nomes vulgares: pingo-de-neve (MG); capim-plumas-brancas (SC).

Ervas cespitosas, $30-90 \mathrm{~cm}$ alt. Lâminas foliares $7-37$ X 0,2-0,4cm, glabras, ápice acuminado. Inflorescência formada por 2-4 racemos digitados, $2-4 \mathrm{~cm}$ compr., facilmente desarticuláveis quando maduros, precedidos de uma espatéola paleácea, com densa pilosidade branca nos pedicelos e ráquis. Espiguetas aos pares, uma séssil frutífera 2,5-3 X 0,5-0,7 mm, e uma pedicelada, neutra, rudimentar, 0,5-1,8 $\mathrm{mm}$ compr. Glumas coriáceo-membranosas, bem mais rígidas que os antécios hialinos, desprendendo-se da inflorescência junto com o restante da espigueta. Lema II de ápice inteiro, mútico ou com arista de 1,2-3mm compr. Unidade de dispersão composta pelo par de espiguetas mais um artículo da ráquis, o pedicelo e o artículo com tricomas brancos e sedosos 3-4 vezes mais longos que a espigueta séssil.

Material examinado: BAHIA: Andaraí, J.R.Pirani et al., CFCR 464, 7/XII/1980 (K, SPF).

Ocorre desde o México até o Brasil, em cerrados, campos e em locais perturbados (Renvoize 1984). Floresce de novembro a maio. A espécie é muito próxima de Andropogon selloanus (Hack.) Hack., que também ocorre no Brasil Central. Andro- 


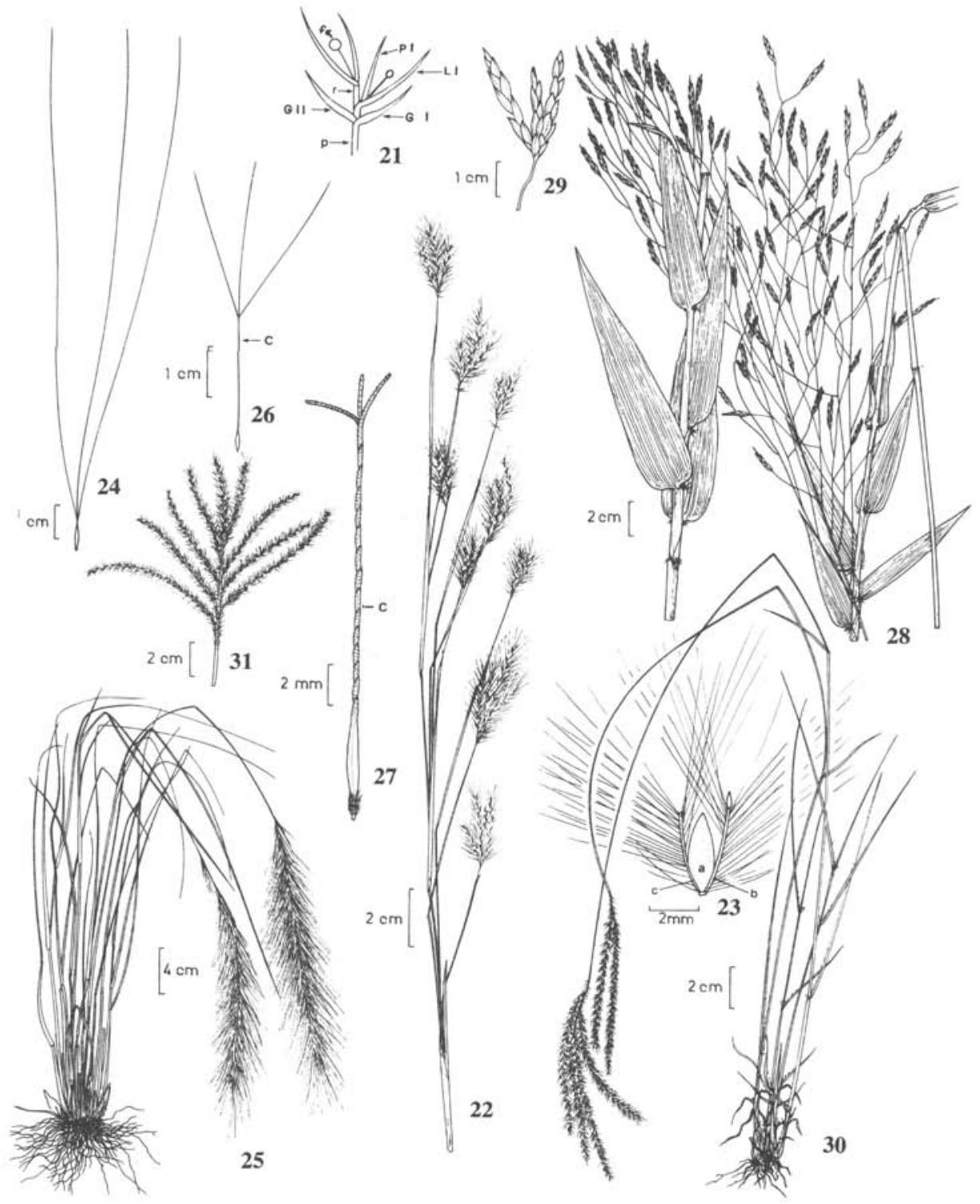

Figura 21. Esquema de uma espigueta biflora - r: ráquila, p: pedicelo, GI: gluma inferior, GII: gluma superior, LI: lema I, PI: pálea I, f: flor. Fig. 22-23. Andropogon leucostachyus: 22. Inflorescência; 23. Unidade de dispersão - a: espigueta séssil, b. espigueta pedicelada rudimentar, c: artículo da ráquis. Fig. 24. Aristida jubata: Lema triaristado e sem coluna. Fig. 25-27. Aristida riparia: 25. Hábito; 26. Lema triaristado com coluna (c); 27. Lema com aristas parcialmente removidas e calo piloso. Fig. 28-29. Aulonemia effusa: 28. Ramo da inflorescência; 29. Conjunto de espiguetas. Fig. 30-31. Axonopus aureus: 30. Hábito; 31. Inflorescência. 
pogon selloanus, entretanto, apresenta lâminas foliares mais curtas e largas e com o ápice navicular. Provavelmente esta última espécie também é utilizada como sempreviva, com o mesmo nome vulgar.

Segundo informações obtidas na empresa Silva Flores (Datas, MG), A. leucostachyus é pouco comercializada, procedendo especialmente da região de Diamantina.

2. Aristida jubata (Arechav.) Herter, Rev. Sudamer. Bot. 6(5-6): 141.1940.

Figura 24.

Nome vulgar: barba-de-bode.

Ervas cespitosas, podendo apresentar rizomas curtos, $50-80 \mathrm{~cm}$ alt. Lâminas foliares filiformes, conduplicadas ou convolutas, rígidas, escabras nas duas faces, 20$50 \times 0,05-0,1 \mathrm{~cm}$; lóbulos da bainha com um tufo de tricomas longos. Panícula aberta, nutante, $25-35 \mathrm{~cm}$ compr. Espiguetas de cor palha. Glumas lanceoladas, aristadas, as inferiores menores do que as superiores; glumas inferiores escabras nas quilhas, 25$30 \mathrm{~mm}$ compr., aristas 3-3,5mm, trinervadas; glumas superiores lisas, 41-43mm compr., aristas 3-5mm, uninervadas. Lemas escabros na metade superior, $14-15 \mathrm{~mm}$ compr., com 1-2 apêndices hialinos apicais, calo $1 \mathrm{~mm}$ compr., agudo e piloso, coluna ausente, aristas retas, subiguais, $130-230 \mathrm{~mm}$ compr. Páleas lanceoladas, 0,5-2 mm compr. Lodículas lanceoladas, 1,2-2mm compr. Unidade de dispersão formada pelo antécio com lema triaristado incluindo o fruto.

Material examinado: MINAS GERAIS: São Tomé das Letras, Serra do Cantagalo, I. Cordeiro et al., CFCR 5849, 3/XI/1984 (SPF).

Amplamente distribuída nos campos sul-brasileiros, atingindo as Regiões Sudeste e Centro-Oeste. Ocorre também no Paraguai, Uruguai e Argentina. Ocorre em campos e cerrados.

As aristas longas dos lemas lhe dão o aspecto ornamental. Os antécios (lemas + páleas), porém, desprendem-se facilmente quando a espigueta está madura, ou após a secagem das inflorescências coletadas ainda imaturas, exigindo provavelmente um tratamento especial do material para evitar grandes perdas.

Segundo informações da empresa Minas Flor, A. jubata é especialmente coletada nos arredores de Montes Claros, em Minas Gerais, apesar de ser coletada também em outras regiões deste Estado e de São Paulo, sendo a sua entrada no depósito especialmente em maio e junho.

3. Aristida riparia Trin., Mém. Acad. St. Petersb. 6,4: 48. 1836.

Figuras 25-27.

Nome vulgar: rabo-de-raposa.

Ervas cespitosas, $90-130 \mathrm{~cm}$ alt. Lâminas foliares planas ou convolutas, 19-70 X $0,3-0,5 \mathrm{~cm}$; face ventral com um tufo de tricomas longos $(5-6 \mathrm{~mm})$ na região atrás da 
lígula; lóbulos da bainha com um tufo de tricomas longos. Panícula espiciforme, linear, $20-44 \mathrm{~cm}$ compr., às vezes subaberta com os ramos inferiores um pouco divergentes. Espiguetas de cor palha. Glumas uninervadas, acuminadas, aristadas, as inferiores maiores do que as superiores; glumas inferiores escabras no dorso, 12 $23 \mathrm{~mm}$ compr., aristas 1,8-6mm; glumas superiores lisas, $10-20 \mathrm{~mm}$ compr., aristas 1,5$4 \mathrm{~mm}$. Lemas tubulosos, geralmente lisos, 6-8 mm compr. (excluindo a arista); calo 0,8$1,5 \mathrm{~mm}$, agudo e densamente piloso com um prolongamento bífido glabro, coluna (10) 14-24(52) mm, aristas retas, a central (26)32-64mm compr., as laterais 22-42(58)mm compr. Páleas lanceoladas, ápice nitidamente bífido, às vezes tridentado, 0,8-1,6mm compr. Lodículas subagudas, $0,8-1,5 \mathrm{~mm}$ compr. Unidade de dispersão formada pelo antécio com lema triaristado incluindo o fruto.

Material examinado: BAHIA: Caitité, R.M.Harley et al. 21141, 9/IV/1980 (CEPEC, K, SPF). MINAS GERAIS: Diamantina, estrada para Conselheiro Mata, H.LonghiWagner et al., CFCR 2968, 2969, 2970, 10/IV/1982 (SPF); Diamantina, estrada para Biribiri, H.Longhi-Wagner et al., CFCR 2946, 8/IV/1982 (SPF); Gouveia, Serra do Barro Preto, H.Longhi-Wagner et al., CFCR 2956, 9/IV/1982 (SPF); Santana do Riacho, Serra do Cipó, H.Longhi-Wagner et al., CFCR 6009, 15/XI/1984 (K, SPF).

Espécie bastante comum no Brasil Central, com limite meridional de distribuição na latitude do Trópico de Capricórnio, ocorrendo também no Paraguai e Bolívia. Em relação à área estudada, a espécie é freqüente especialmente nos cerrados e campos rupestres dos arredores de Diamantina, ocorrendo em solos arenosos ou entre pedras.

Segundo informações da empresa Minas Flor, A. riparia é coletada nos arredores de Diamantina, sendo a sua entrada no depósito especialmente em outubro. $\mathrm{O}$ informante da empresa Silva Flores (Datas, MG), mencionou que a espécie é proveniente não só de Diamantina, como também de várias regiões de Goiás, onde sua entrada no depósito se dá especialmente em abril.

\section{Aulonemia effusa (Hack.) McClure, Smiths. Contrib. Bot. Washington 9. 1973.} Figuras 28-29, 42.

Nomes vulgares: andrequicé, capim-chorão, indequicé.

Ervas cespitosas, 2-3m alt., com rizomas paquimorfos (curtos e espessos). Colmos eretos, lenhosos, entrenós ocos. Lâminas foliares eretas, com pecíolos muito curtos, de base arredondada. Panícula ereta, $30-40 \mathrm{~cm}$ compr., aberta. Espiguetas glabras, $25-28 \mathrm{X}$ ca. $2 \mathrm{~mm}$, plurifloras; glumas agudas, as inferiores $3-4 \mathrm{~mm}$ compr., trinervadas, as superiores 4-6mm compr., 5-nervadas; 2 glumas transicionais semirígidas, 7,5-9mm compr., ápice com múcron de 0,5-0,8mm, 9-nervadas, nervuras longitudinais unidas por nervuras transversais mais tênues; 3 antécios completos com flor monoclina mais um antécio apical neutro e reduzido só ao lema. Lemas 9-10mm compr., 1,3-1,5mm larg., semelhantes às glumas transicionais. Páleas com sulco longitudinal pronunciado. 
Material examinado: MINAS GERAIS: Congonhas do Norte, Serra da Mangabeira, A.Furlan et al., CFSC 8450, 23/IV/1982 (K, SPF); Diamantina, estrada para Biribiri, H.Longhi-Wagner et al., CFCR 2955, 8/IV/1982 (SPF); Diamantina, estrada para Milho Verde, N.L.Menezes et al., CFCR 3297, 10/IV/1982 (SPF); Diamantina, estrada para Sopa, E.Simonis \& I.Cordeiro, CFCR 4002, 22/II/1983 (SPF, U).

Gramínea bambusóide que ocorre em Minas Gerais, nas encostas rochosas da Serra do Espinhaço, formando grandes populações. Não há outros dados de ocorrência, nem sobre sua fenologia, mas parece florescer de $2 \mathrm{em} 2$ anos, entre janeiro e abril (espécies de ciclo plurianual são comuns na subfamília Bambusoideae).

As inflorescências cinéreas de $A$. effusa são comercializadas principalmente na região de Diamantina e Presidente Juscelino (MG). Segundo informações da empresa Silva Flores (Datas, MG), esta espécie só aparece em períodos intermitentes longos, às vezes de 7 em 7 anos, enquanto que a informação obtida da empresa Minas Flor (Diamantina) indica que é comercializada de 2 em 2 anos.

5. Axonopus aureus P.Beauv., Ess. Agrost. 12. 1812.

Figuras 30-31.

Nome vulgar: capim-ourinho.

Ervas cespitosas, $30-110 \mathrm{~cm}$ alt. Lâminas foliares $6-30$ X $0,2-0,5 \mathrm{~cm}$. Inflorescência formada por 2-14 ramos unilaterais espiciformes de 2,5-13 cm compr., digitados ou subdigitados; ráquis com tricomas de $4-5 \mathrm{~mm}$ compr., dourados, de base tuberculada. Espiguetas 2-2,5 X ca. 1mm. Gluma I ausente; gluma II e lema I semelhantes, só com 2 nervuras laterais, membranoso-hialinas, levemente douradas, com tricomas curtos (ca. $1 \mathrm{~mm}$ ), branco-dourados. Antécio I reduzido ao lema; antécio II coriáceo, frutífero, dourado, 2-2,5 X 0,8-1 mm, fina e transversalmente rugoso.

Material examinado: BAHIA: Senhor do Bonfim, Serra de Santana, 650-900 m., J.R. Pirani et al., CFCR 7628, 26/XII/1984 (K, SPF); Morro do Chapéu, Cachoeira do Rio Ferro Doido, A.Furlan et al., CFCR 315, 30/XI/1980 (K, SPF); Mucugê, estrada para Guiné, a 5 km de Mucugê, A.Furlan et al., CFCR 1943, 7/IX/1981 (K, SPF). MINAS GERAIS: Grão-Mogol, estrada para Cristália, I.Cordeiro et al., CFCR 927, 15/IV/1981 (SPF); Congonhas do Norte, $3 \mathrm{~km}$ de Congonhas na estrada para Conceição, A. Furlan et al., CFSC 8310, 20/IV/1982 (K, SPF); estrada Sacramento-Franca, I.Cor-deiro et al., CFCR 658, 30/I/1981 (K, SPF); Gouveia, Fazenda Batieiroca, T.Cerati et al., CFCR 4259, 25/III/1984 (SP, SPF); Santana do Pirapama, Serra Mineira (Serra do Cipó), Fazenda Inhame, H.Longhi-Wagner et al., CFSC 8232, 20/III/1982 (ICN, SPF).

Amplamente distribuída, desde a América Central até o Brasil, não atingindo o extremo sul do país. Nos campos rupestres da Cadeia do Espinhaço, forma freqüentemente populações que ocupam área considerável, dando aspecto dourado ao campo na 
época da floração, que se dá especialmente de outubro-novembro a abril-julho. Apresenta-se bastante variável quanto ao número e comprimento dos ramos da inflorescência. De acordo com Renvoize (1984), a espécie ocorre também em cerrados e restingas.

Segundo informante da empresa Silva Flores (Datas, MG), o capim-ourinho já foi uma das "sempre-vivas" mais procuradas no comércio há cerca de 4 anos atrás, mas atualmente tem expressão reduzida. As áreas de maior produção são adjacentes a Diamantina, como Presidente Kubitschek, Batatal e São João da Chapada.

6. Axonopus brasiliensis (Spreng.) Kuhlm., Comm. Lin. Telegr. Mato GrossoAmazonas 67, Bot. 11: 47. 1922.

Figuras 32-33.

Nomes vulgares: pingo-de-neve (MG); capim-branco (SC).

Ervas cespitosas, $20-90 \mathrm{~cm}$ alt., base fibrosa freqüentemente com marcas de queimada. Lâminas foliares $10-40$ X 0,1-0,3cm. Inflorescência formada por 2-3 ramos unilaterais espiciformes de $3-13 \mathrm{~cm}$ compr., digitados ou subdigitados; ráquis e espiguetas com pilosidade densa, tricomas brancos de base tuberculada. Espiguetas 2,5-3 X 0,6-0,8 mm. Gluma I ausente; gluma II e lema I semelhantes, a gluma II 5nervada, o lema I 3-nervado, nervuras salientes, ambos com tricomas longos (ca. $4 \mathrm{~mm}$ ), brancos, de base fortemente tuberculada, densos. Antécio I reduzido ao lema; antécio II frutífero, subcoriáceo, castanho-escuro, agudo, $2,5 \times$ 0,8mm, liso.

Material examinado: MINAS GERAIS: Gouveia, Fazenda Batieiroca, T. Cerati et al., CFCR 4256, 25/III/1984 (SP, SPF); estrada Diamantina-Sopa, a 25 km de Diamantina, A.M.Giulietti et al., CFCR 2362, 30/X/1981 (SPF); Diamantina, estrada para Mendanha, ca. $10 \mathrm{~km}$ de Diamantina, R. Mello-Silva et al., CFCR 5365, 12/X/ 1984 (SPF); Santana do Riacho, Serra do Cipó, Morro do Palácio, l. Cordeiro et al., CFSC 6709, 7/XI/1980 (SP, SPF); km 107 da rodovia Belo Horizonte-Conceição do Mato Dentro, Chapéu do Sol,H.Longhi-Wagner et al., CFCR 5913, 13/XI/1984 (K, SPF).

Ocorre no Paraguai e no Brasil, sendo citada desde o Maranhão até Santa Catarina (Smith et al. 1982), ocorrendo também no Rio Grande do Sul, sendo este provavelmente o limite meridional de ocorrência da espécie. Habita os campos rupestres, instalando-se sobre solos pedregosos, arenosos ou mesmo nos brejos. Apresenta floração precoce, em setembro, após as queimadas e as primeiras chuvas, estendendo-se o período fértil até março-abril. A espécie apresenta pouca expressão no comércio de "sempre-vivas" em Diamantina.

7. Cymbopogon densiflorus (Steud.) Stapf, in Prain, Fl. Trop. Afr. 9: 289. 1919. Andropogon densiflorus Steud., Syn. Pl. Glum. 1: 386. 1854.

Figura 34. 
Nomes vulgares: capim-cacheado, capim-de-São-José.

Ervas cespitosas, $100-180 \mathrm{~cm}$ alt. Lâminas foliares $30-50$ X 0,8-3cm, glabras. Panícula contraída, densiflora, subglobosa, $20-30 \mathrm{~cm}$ compr., com dois racemos por espatéola. Espiguetas em pares, uma séssil frutífera, 3-5mm compr., e uma pedicelada neutra ou estaminada, 3-4mm compr., múticas. Glumas coriáceo-membranáceas, mais rígidas do que os antécios hialinos. Lema II inteiro, com arista de 5-8mm compr. que se sobressaem da espigueta. Unidade de dispersão composta pelo par de espiguetas mais um artículo da ráquis, o pedicelo da espigueta e o artículo curtamente pilosos.

Material examinado: MINAS GERAIS: Gouveia, Faz. Batieiroca, Giulietti et al., CFCR 4264, 25/III/1984 (SPF).

Espécie africana, introduzida no Brasil. Pode ocorrer subespontaneamente no cerrado.

8. Gynerium sagittatum (Aubl.) P.Beauv., Ess. Agrost. 138, 153. 1812.

Figuras 35-36.

Nomes vulgares: cana-brava (MG, SC); ubá (SC).

Ervas dióicas, cespitosas, 2-5(6) m alt.; colmos sólidos cobertos pelas bainhas foliares persistentes, imbricadas. Folhas notadamente de disposição dística, formando um "leque" na parte superior dos colmos; lâminas foliares até 200 X 4-6cm. Panícula 1-3 m compr., a pistilada plumosa e semi-contraída, a estaminada glabra e aberta. Espiguetas pistiladas 8-9mm compr., bifloras, pilosas, tricomas longos superando a espigueta, lemas com curta arista apical; espiguetas estaminadas bifloras, glabras, 2 estames por flor, lemas múticos.

Material examinado: ESPÍRITO SANTO: Guarapari, W.W.Thomas et al. 6102, 24/II/1988 (SPF).

Apresenta ampla distribuição geográfica, ocorrendo desde o México e Antilhas até Santa Catarina, no sul do Brasil, limite meridional da espécie. Ocorre em barrancos úmidos, em margem de rios, banhados, solos arenosos em margem de rios e correntes d'água. Em Minas Gerais é freqüente principalmente em Baldim e ao longo do Rio das Velhas. Distingue-se facilmente pelo seu porte robusto e pela disposição característica das folhas novas no ápice dos colmos. Floresce de janeiro a maio.

Tanto as inflorescências pistiladas quanto as estaminadas são ornamentais. É a planta que fornece as mais longas inflorescências de "sempre-vivas", com 1 a 3 m de comprimento. Estas são coletadas ainda imaturas e colocadas para secar. Esta espécie é bastante comercializada, sendo coletada anualmente grande quantidade de inflorescências, conhecidas como "pés" pelos comerciantes. 
É referido também o uso desta espécie como fornecedora de celulose para a indústria de papel, utilização na construção rural e como proteção dos barrancos de rios contra a erosão (Smith et al. 1981).

9. Loudetiopsis chrysothrix (Nees) Conert, Bot. Jahrb. Syst. 77 (2-3):277. 1957.

Tristachya chrysothrix Nees, Agrost. Bras. 460. 1829.

Diandrostachya chrysothrix(Nees) J.Felix, Journ. Agric. Trop. Bot. d'Applique 7: 408. 1906.

Figuras 37-38.

Nomes vulgares: brinco-de-princesa, brinco-de-ouro (MG); trigo-da-felicidade (DF).

Ervas cespitosas, $50-80 \mathrm{~cm}$ alt. Lâminas foliares acuminadas, escabras, glabras ou pilosas na base. Panícula com ramos laterais de $1-4 \mathrm{~cm}$ compr., nutantes, as espiguetas formando grupos de duas a três no ápice dos mesmos, parecendo uma só espigueta pedicelada; ramos laterais da panícula, pedicelos e glumas inferiores com pilosidade densa, tricomas dourados. Espiguetas 12-14mm compr., bifloras, antécio inferior com flor estaminada de 2 estames ou neutro; antécio superior frutífero, 2 estames. Glumas inferiores ca. $8 \mathrm{~mm}$ compr., trinervadas, com tricomas dourados de base fortemente tuberculada e marrom; glumas superiores $14-15 \mathrm{~mm}$ compr., subuladas, trinervadas, com tricomas brancos esparsos na margem superior; lema I glabro e mútico; lema II de ápice bífido, com arista geniculada de $4-5 \mathrm{~cm}$.

Material examinado: MINAS GERAIS: São Tomé das Letras, Serra de São Tomé, I. Cordeiro et al., CFCR 5731, 30/X/1984 (SPF); Diamantina, estrada para Mendanha, ca. $10 \mathrm{~km}$ de Diamantina, E.M.Isejima et al., CFCR 5352, 12/X/1984 (SPF); Diamantina, estrada para Biribiri, H.Longhi-Wagner et al., CFCR 2953, 8/VI/1982 (SPF); Diamantina, estrada para Milho Verde, H.Longhi-Wagner et al., CFCR 2965, 10/IV/ 1982 (SPF); Datas, arredores da cidade, E.Simonis \& I.Cordeiro, CFCR 4028, 28/II/ 1983 (SPF); Gouveia, fazenda Batieiroca, T. Cerati et al., CFCR 4260, 25/III/1984 (SP, SPF); Sacramento, I.Cordeiro, CFCR 660, 30/I/1981 (SPF).

Ocorre apenas no Brasil, de Minas Gerais até São Paulo (Doell 1878). É referida por Heringer et al. (1977) como uma das gramíneas componentes dos cerrados brasileiros, sob o nome de Tristachya chrysothrix Nees. Ocorre no cerrado e em campos rupestres, formando populações que cobrem uma área razoável ou como touceiras isoladas. É facilmente reconhecida pelas espiguetas douradas, com arista desenvolvida. Floresce de janeiro a abril.

Esta espécie ocorre com freqüência na região do Planalto de Diamantina, sendo comercializada pelas empresas locais.

\section{Schizachyrium condensatum (Kunth) Nees, Agrost. Bras. 333. 1829.}

Figura 39. 
Nome vulgar: rabo-de-burro.

Plantas perenes, $60-150 \mathrm{~cm}$ alt., com rizomas delgados e curtos. Colmos eretos, entrenós inferiores curtos e grossos. Lâminas foliares glabras, 8-28 X 0,3-1cm. Panícula contraída e densa, ramificada, 5-45 compr., composta por um conjunto de racemos de $1-4 \mathrm{~cm}$ compr., flexuosos quando maduros, cada racemo precedido de uma espatéola cor-de-vinho; as espatéolas permanecem na inflorescência após a queda das espiguetas, dando-lhe um aspecto típico. Espiguetas aos pares, uma séssil frutífera 3,55,5 X 0,3-0,5mm, e uma pedicelada neutra e rudimentar, 1-2 X ca. $1 \mathrm{~mm}$. Glumas coriáceo-membranáceas, bem mais rígidas do que os antécios hialinos. Lema II profundamente bipartido, com arista dorsal de $7-10 \mathrm{~mm}$ compr., que se sobressai da espigueta. Unidade de dispersão composta pelo par de espiguetas mais um artículo da ráquis, com pedicelo da espigueta e artículo pilosos.

Material examinado: BAHIA: Campinas, H.S.Irwin et al 14711, 13/IV/1966 (SP).

Esta espécie ocorre desde o México e Antilhas até Argentina e Uruguai (Smith et al. 1982). No Brasil, ocorre desde o Mato Grosso, Bahia e Minas Gerais até o Rio Grande do Sul. Habita campos e cerrados, geralmente em áreas perturbadas. Forma extensas populações nos campos rupestres das serras de Diamantina, porém sem muita expressão no comércio de "sempre-vivas" em Minas Gerais.

11. Setaria tenax (Richard) Desv., Opusc.: 78.1831.

Figura 40.

Nome vulgar: rabo-de-gato.

Plantas anuais, $15-130 \mathrm{~cm}$ alt., cespitosas, com rizomas curtos, colmos eretos ou geniculados na base. Lâminas foliares $18-27 \times 0,8-2,5 \mathrm{~cm}$, glabras ou pilosas. Panícula espiciforme, cilíndrica, esverdeada, ercta, 9-3,5 X 2-4cm (incluindo as aristas), com cerdas persistentes de $1-1,5 \mathrm{~cm}$ compr., ráquis pilosa, os ramos basais às vezes divergentes; cerdas com asperezas antrorsas e retrorsas, o que torna a panícula aderente. Espiguetas 2-2,5mm compr., subglobosas. Glumas membranosas, caindo junto com as espiguetas; glumas inferiores $0,8-1,2 \mathrm{~mm}$ compr., ca. $1 / 3$ do comprimento da espigueta; glumas superiores $1,5-1,7 \mathrm{~mm}$ compr., alcançando $1 / 2$ do comprimento da espigueta. Antécio I de consistência igual a das glumas, 2-2,5mm compr., com flor estaminada; antécio II frutífero, rígido, apiculado; lema II 1,5-2mm compr., 1,5 larg., com rugosidade transversal.

Material examinado: SÃO PAULO: São Paulo, Jardim Julia, I.Gemtchunicov s.n., 18/IV/1948 (SP).

Ocorre desde o México até o Brasil e Paraguai. No Brasil, ocorre até o Paraná, que parece ser seu limite meridional de distribuição. Ocorre em cerrado e caatinga. $\mathrm{O}$ material comercializado desta espécie procede especialmente de São Paulo. 


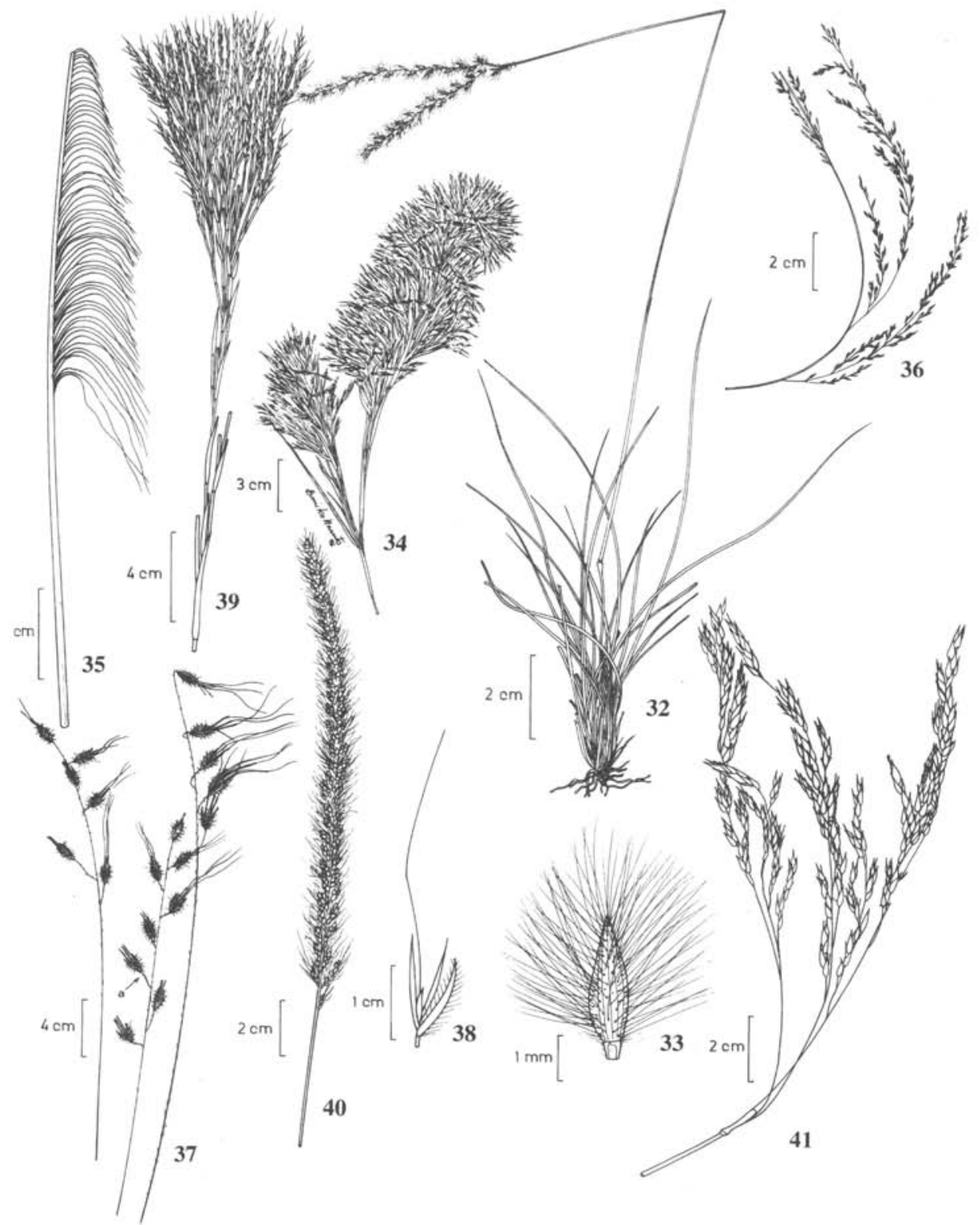

Figura 32-33. Axonopus brasiliensis: 32. Hábito; 33. Espigueta (retirado de Renvoise 1984). Fig. 34. Cymbopogon densiflorus: Inflorescência. Fig. 35-36. Gynerium sagittatum: 35. Inflorescência pistilada (adaptado de Renvoize 1984); 36. Ramo da inflorescência estaminada. Fig. 37-38. Loudetiopsis chrysothrix: 37. Inflorescência (a: par de espiguetas); 38. Espigueta com gluma inferior pilosa. Fig. 39. Schizachyrium condensatum: Inflorescência (adaptado de Renvoize 1984). Fig. 40. Setaria tenax: Inflorescência. Fig. 41. Sorghum arundinaceum: Ramo da inflorescência. 


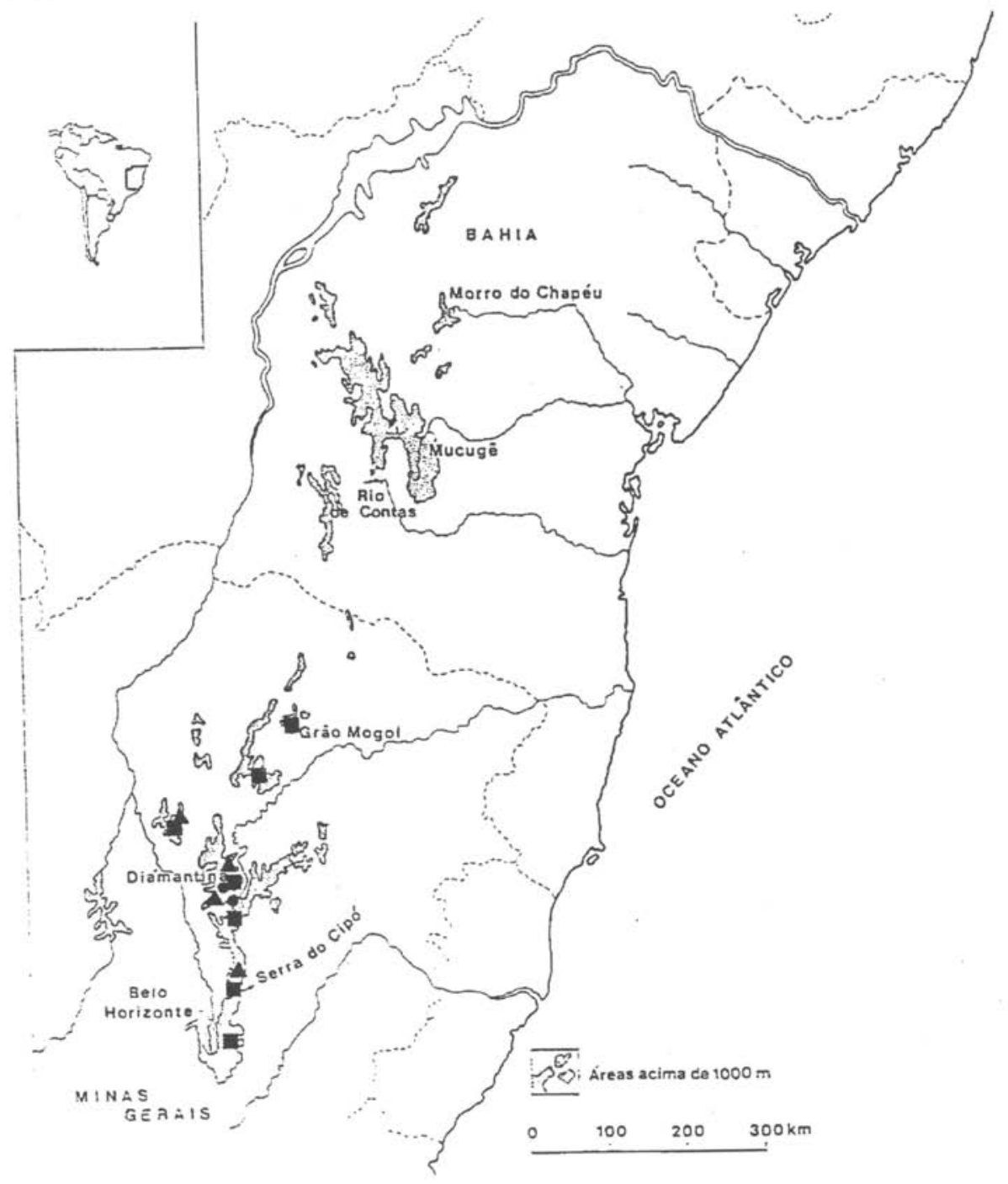

Figura 42. Mapa da Cadeia do Espinhaço, Brasil, mostrando a distribuição geográfica de algumas espécies: Aulonemia effusa $\bullet$; Cephalostemon ridelianus $\mathbf{\square}$; Rhynchospora speciosa $\mathbf{\Lambda}$.

12. Sorghum arundinaceum (Desv.) Stapf in Prain, Fl. Trop. Afr. 9: 114.1917. Figura 41.

Nome vulgar: arrozinho.

Ervas cespitosas, $30-40 \mathrm{~cm}$ alt. Lâminas foliares $5-75$ X $0,7-7 \mathrm{~cm}$, com a base 
largo-arredondada geralmente abraçando o colmo. Panícula 10-60 cm compr., aberta. Espiguetas agrupadas em pares, uma séssil e uma pedicelada, exceto no ápice dos ramos onde o grupo é formado por uma espigueta séssil e duas pediceladas. Espiguetas acuminadas, a séssil frutífera, 4-9 X 2-3mm, glabra ou pubescente, a pedicelada estaminada ou neutra, estreito-lanceolada, $7 \mathrm{X} \mathrm{ca}$. $1 \mathrm{~mm}$. Glumas coriáceas, bem mais rígidas que os antécios hialinos. Lema II da espigueta séssil, profundamente bipartido, com arista dorsal de $5-7 \mathrm{~mm}$ compr. que sobressai $2-3 \mathrm{~mm}$ da espigueta, ou mútico, podendo ocorrer espiguetas aristadas e múticas na mesma inflorescência. Unidade de dispersão formada pela espigueta séssil, espigueta pedicelada e um artículo da ráquis.

Material examinado: MINAS GERAIS: Ituiutaba, A.Macedo 2474, 10/VII/1950(SP).

Esta espécie é africana, tendo sida introduzida no Brasil e em outros países da América do Sul como planta forrageira, sempre associada a locais perturbados. Floresce quase durante todo o ano (Smith et al. 1982).

É pouco comercializada na região de Diamantina, segundo a empresa Silva Flores (Datas, MG).

\section{CYPERACEAE}

1. Rhynchospora globosa (H.B.K.) Roem. \& Schult., Syst. Veg. 2: 89.

Figuras 43-45.

Nome vulgar: espeta-nariz.

Ervas rizomatosas, cespitosas. Folhas basilares ou algumas na parte inferior do pedúnculo linear-lanceoladas, com bainha invaginante aberta, 45-66 X 0,2-0,4cm, glabras, margem escabra, tricomas curtos e adpressos. Pedúnculo distintamente trígono, liso, glabro, longitudinalmente estriado, 30-80(100)cm compr. Inflorescência capituliforme terminal, globosa, uma por planta; invólucro composto por brácteas ovais a orbiculares, as mais exteriores mucronadas, $1-1,7 \times 0,5-0,8 \mathrm{~cm}$, paleáceas, rígidas a cartáceas, margem irregularmente fimbriada; espiguetas lanceoladas, glumas cilíndricas, ovais, carenadas, as 4 inferiores mais estéreis com quilha ciliada, a $5^{\mathrm{a}} \mathrm{com}$ 1 flor pistilada, as demais envolvendo flores estaminadas. Flores aclamídeas, as estaminadas com 3 estames de filetes curtos unidos na base e anteras oblongas, a pistilada com 5 setas hipogínicas pilosas e ovário súpero, oblongo, com estilete longo de base dilatada e ápice com 2 lobos muito pequenos. Cariopse obovóide, biconvexa, paleácea, coroada com rostro cônico curto (a base do estilete persistente).

Material examinado: BAHIA: Pico das Almas, $25 \mathrm{~km}$ WNW da Vila de Rio de Contas, R.M.Harley et al. 19642, 18/III/1977 (K, SPF); Palmeiras, Serra dos Lençóis, Morro do Pai Inácio, R.M.Harley et al. 22278, 21/V/1980 (K, SPF). MINAS GERAIS: Couto Magalhães, Fazenda das Abóboras, M.G. Wanderley et al., CFCR 4559, 16/VII/1984 
(K, NY, SP, SPF); Joaquim Felício, Serra do Cabral, M.L.Kawasaki et al., CFCR 8083, 31/VIII/1985 (NY, SPF); Diamantina, estrada para Mendanha, E.M.Isejima et al., CFCR 5368, 12/X/1984 (NY, SPF);R.Mello-Silva et al., CFCR 7935, 3/VIII/1985 (NY, SPF); estrada Diamantina-Biribiri, R.Mello-Silva et al., CFCR 5559, 15/X/1984 (NY, SPF); Santana do Riacho, Serra do Cipó, km 109 da estrada Lagoa SantaConceição do Mato Dentro, E.Forero et al., CFSC 8760, 6/IX/1980 (SP); SÃO PAULO: São Paulo, Butantã, A.B.Joly s.n., 20/XII/1948 (SPF 16577), A.B.Joly s.n., 3/XII/1946 (SPF 16576); São Paulo, Congonhas, W.Hoehne \& H.N.Moldenke 2728, 23/IX/1948 (NY, SPF).

Apresenta ampla distribuição pelo Brasil, ocorrendo desde os campos da Amazônia até São Paulo e Rio de Janeiro. É bastante freqüente na Cadeia do Espinhaço especialmente em Diamantina e Serra do Cipó, aparecendo principalmente em áreas brejosas, muitas vezes associada aos bancos de Sphagnum e outras plantas típicas desses ambientes (Xyridaceae e outras Cyperaceae). A espécie é característica pelas folhas conduplicadas e finas e pelo capítulo globoso com invólucro de brácteas rígidas, arredondadas, com ápice mucronado e paleáceas. A floração se concentra em setembro-novembro.

Esta espécie é bastante coletada e, quando seca, mantém a coloração paleáceobrilhante das brácteas involucrais.

\section{Rhynchospora speciosa (Kunth) Boeck., Linnaea 37. 1873.}

Figuras 42, 46-47.

Nomes vulgares: capim-estrela, estrela-branca, estrelinha.

Ervas rizomatosas, cespitosas. Folhas basilares ou algumas na parte inferior do pedúnculo, longa e estreitamente lanceoladas, com bainha invaginante truncada (aberta), 38-99 X 0,4-0,6cm, glabras, brilhantes na face adaxial, margem escabra com tricomas esparsos curtos e adpressos, nervura mediana impressa na face adaxial e proeminente na face abaxial, nervuras laterais paralelas pouco evidentes em ambas as faces. Pedúnculo tornando-se trígono no ápice, liso, glabro, longitudinalmente estriado, $60-160 \mathrm{~cm}$ compr. Inflorescência capituliforme terminal subglobosa, uma por planta; invólucro composto de brácteas foliáceas, as exteriores bem maiores chegando a $17 \mathrm{~cm}$ compr., na base ca. $8 \mathrm{~mm}$ larg., com o terço basal alvo e a porção restante verde, margem curtamente pilosa para o ápice; brácteas interiores progressivamente menores e gradualmente destituídas da coloração verde e alva; espiguetas densamente dispostas, lanceoladas, glumas espiraladas, imbricadas, convexas e compressas, quilhadas com a quilha serrilhada, as 3 mais inferiores estéreis. Flores 3-5 por espigueta, aclamídeas, a mais inferior monoclina com 3 estames e ovário súpero com 1 estilete bífido com ramos caducos, dilatado na base e persistente na cariopse, as mais superiores estaminadas com 3 estames de anteras oblongas. Cariopse lenticularobovada, biconvexa, transversalmente rugosa, ferrugínea, coroada com rostro cônico curto (base do estilete persistente). 
Material examinado: MINAS GERAIS: Rio Vermelho, Pedra Menina, Serra do Ambrósio, Fazenda Vargem do Anjo, J.R.Pirani et al., CFCR 7840, 1/VIII/1985 (NY, SPF); Joaquim Felício, Serra do Cabral, estrada para Várzea da Palma, M.L.Kawasaki et al., CFCR 8094, 31/VIII/1985 (NY, SPF); Diamantina, estrada Diamantina-Curvelo, A.M. Giulietti et al., CFCR 2264, 30/X/1981 (NY, SPF); Diamantina, estrada Diamantina-Biribiri, J.R.Pirani et al., CFCR 5556, 15/X/1984 (NY, SPF); A.Furlan et al., CFCR 2556, 31/X/1981 (NY, SPF); Gouveia, Fazenda Batieiroca, A.M.Giu-lietti et al., CFCR 4255, 25/III/1984 (NY, SPF).

Esta espécie é freqüente nos campos rupestres da região de Diamantina e serras próximas, aparecendo também na Serra do Cabral, mais ao norte. Habita sempre terrenos brejosos com solos orgânicos e ácidos, geralmente de coloração escura, formando extensas e densas populações freqüentemente associadas a outras plantas típicas desses ambientes, como Xyridaceae, Eriocaulaceae, Droseraceae, Lentibulariaceae, Selaginella e Sphagnum. É facilmente distinta de outras espécies de Rhynchospora por seus longos eixos caulinares com a inflorescência terminal envolvida por invólucro de longas brácteas de base branca e ápice verde. A floração concentrase na primavera e verão, principalmente de setembro a dezembro.

Apresenta pequeno interesse comercial, segundo informante da empresa Silva Flores (Datas, MG), sendo coletada por toda a região de Diamantina. Embora no estado fresco seja bastante vistosa, não alcança bom preço de mercado porque apresenta as brácteas enrugadas, quando secas.

\section{RAPATEACEAE}

\section{Cephalostemon riedelianus Koern., Linnaea 37: 445. 1873.}

Figuras 42, 48-50.

Nomes vulgares: botão-verde, estrela-amarela.

Ervas cespitosas, glabras, com raízes esponjosas espessas e alvas. Folhas em roseta a subdísticas, $20-60 \times 0,5 \mathrm{~cm}$, lineares, obtusas, com bainha invaginante obliquamente conduplicada ou subplana de $2,5 \mathrm{~cm}$ larg.; nervura mediana saliente e amarela na face abaxial, nervuras laterais pouco evidentes. Escapos 1-2 por planta, eretos, cilíndricos, 2-3,5mm diâm., (11)30-100 (140)cm compr., dilatados no ápice, amarelo-esverdeados, com 6-9 costelas salientes de cor amarela; espata basal fechada, 13-30cm compr., expandida no ápice em lâmina plana a canaliculada. Inflorescência capituliforme subglobosa, constituída por denso agregado de pequenas inflorescências alongadas, unifloras, envolta na base por 2 brácteas espatáceas livres, com base orbicular-oval e longa projeção lanceolada, rígidas, verde-amareladas, 3,5-6 (9) $\mathrm{cm}$ compr. Flores monoclinas, actinomorfas, sésseis, cada uma sobre um eixo curto coberto de numerosas bractéolas densamente imbricadas, lanceoladas, com ápice acuminado subulado, hialinas na base, côncavas, ca. $9 \mathrm{~mm}$ compr.; sépalas 3 , unidas na 
base, oval-lanceoladas, côncavas, cartáceas, amareladas; pétalas 3, amarelas, unidas na base em tubo hialino, largamente espatuladas, retusas e apiculadas; estames 6; ovário súpero, 3-locular, estilete filiforme. Cápsula obovóide loculicida, 3-valvar, valvas cartáceas; sementes 3 .

Material examinado: MINAS GERAIS: Grão-Mogol, próximo ao Rio Itacambiruçu, D.C.Zappi et al., CFCR 8445, 4/IX/1985 (MBM, MO, SPF); Joaquim Felício, Serra do Cabral, B.Stannard et al., CFCR 6293, 22/XI/1984 (SPF); Itacambira, estrada para Montes Claro, M.L.Kawasaki et al., CFCR 6587, 29/XI/1984 (SPF); Diamantina, estrada Diamantina-Mendanha, I.Cordeiro et al., CFCR 563, 12/XII/1980 (SPF); Diamantina, estrada Diamantina-Curvelo, Giulietti et al., CFCR 2281, 30/X/1981 (SPF); Gouveia, Serra do Barro Preto, A.Furlan et al., CFCR 3206, 9/IV/1982 (SPF); Datas, estrada Datas-Gouveia, T.Cerati et al., CFCR 4279, 25/III/1984 (SPF); Santana do Riacho, Serra do Cipó, rodovia Belo Horizonte-Conceição do Mato Dentro, km 111 , E.Forero et al., CFSC 8780, 6/IX/1980 (SP); km 121, J.Semir \& A.B.Joly, CFSC 3731, 5/I/1973 (SP); km 132-135, N.L.Menezes, CFSC 3476, 10/IX/1972 (SP); km 142, A.B.Joly et al., CFSC 2114, 25/V/1972 (SP); Barão de Cocais, estrada para Caeté, N.Hensold et al., CFCR 2815, 11/1/1982 (MICH, SPF).

Esta espécie é comum nas serras da Cadeia do Espinhaço de Minas Gerais, formando densas e extensas populações nos campos brejosos, com solo orgânico escuro e ácido, onde se associa a espécies de Cyperaceae, Xyridaceae, Eriocaulaceae e Poaceae (Gramineae). Floresce praticamente ao longo de todo o ano. É facilmente distinta no campo pelos longos escapos portando no ápice inflorescências globosas com duas grandes brácteas involucrais e com bractéolas involucrais grandes, acuminadas e numerosas envolvendo as flores delicadas e amarelas. Tais inflorescências prestam-se como "sempre-vivas" ornamentais, porém não alcançando preço muito compensador, tendendo diminuir cada vez mais sua comercialização.

\section{XYRIDACEAE}

1. Xyris ciliata Thunb., Decad. Pl. Brasil. 3: 27. 1821.

Figura 51 .

Nome vulgar: botão-marrom.

Ervas cespitosas. Raízes espessas. Folhas basilares, $8-16 \mathrm{~cm}$ compr.; bainhas pouco distintas das lâminas, base escura, margens ciliadas; lâmina ensiforme com ápice obtuso ou mucronado, $40-70 \mathrm{~cm}$ compr., lígula ausente; bainhas do escapo menores que as folhas, sem lâmina. Escapo bicostelado, costelas escabras, $30-50 \mathrm{~cm}$ compr. Espiga cilíndrica, multiflora (+ 10 flores), ca. $2 \mathrm{~cm}$ compr.; brácteas castanhas, concolores, opacas, glabras, sem carena, levemente laceradas, brácteas estéreis basais reduzidas, elípticas, brácteas medianas arredondadas $0,5-0,6 \times 0,3-0,5 \mathrm{~cm}$; sépalas laterais livres, inequilaterais, linear-espatuladas, $0,5 \mathrm{~cm}$ compr., carena estreito-alada, 


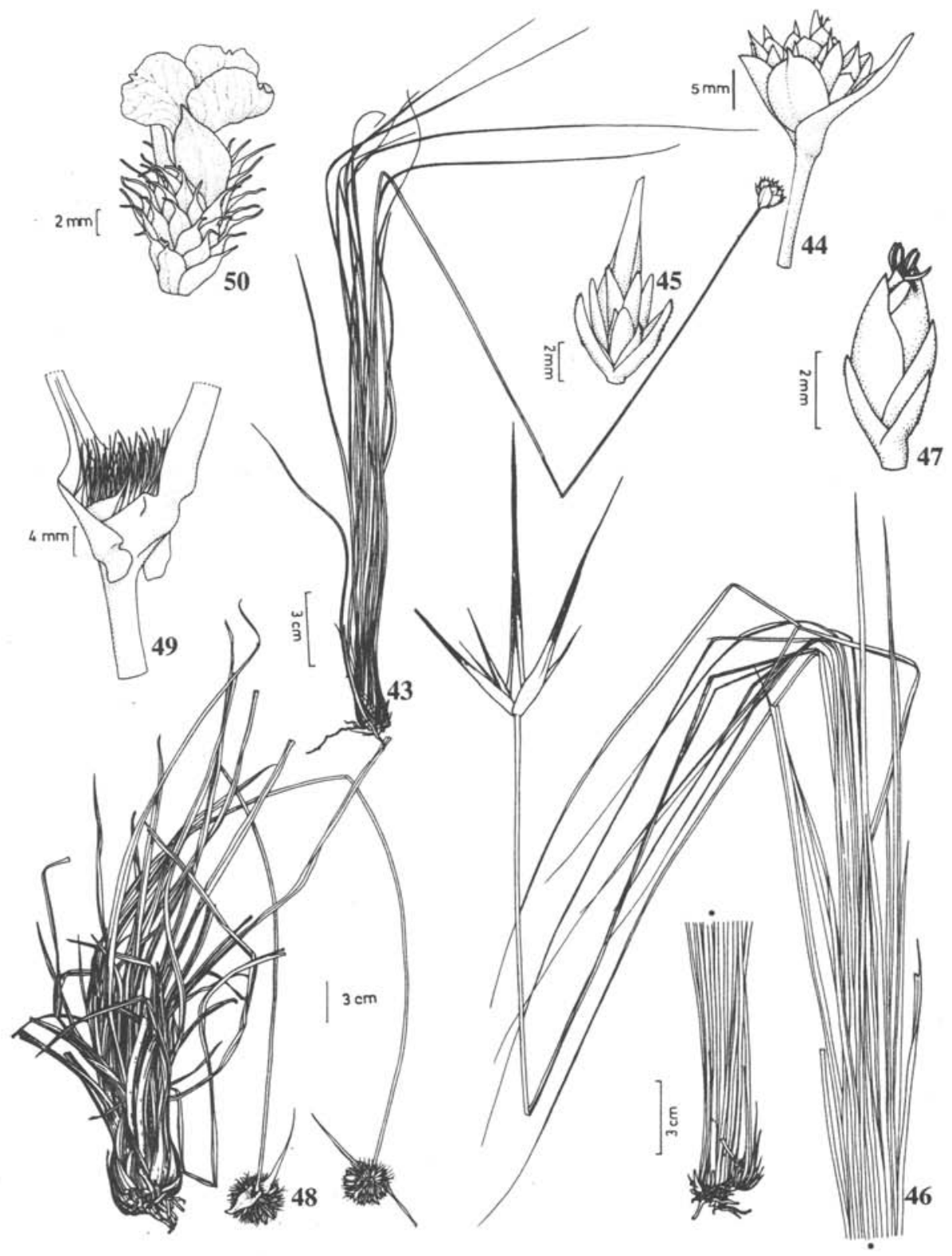

Figura 43-45. Rhynchospora globosa: 43. Hábito; 44. Inflorescência; 45. Espigueta. Fig. 46-47. Rhynchospora speciosa: 46. Hábito; 47. Espigueta. Fig. 48-50. Cephalostemon ridelianus (retirado de Pirani \& Giulietti 1989): 48. Hábito; 49. Detalhe das espatas envolvendo a inflorescência capituliforme; 50. Inflorescência uniflora isolada. 


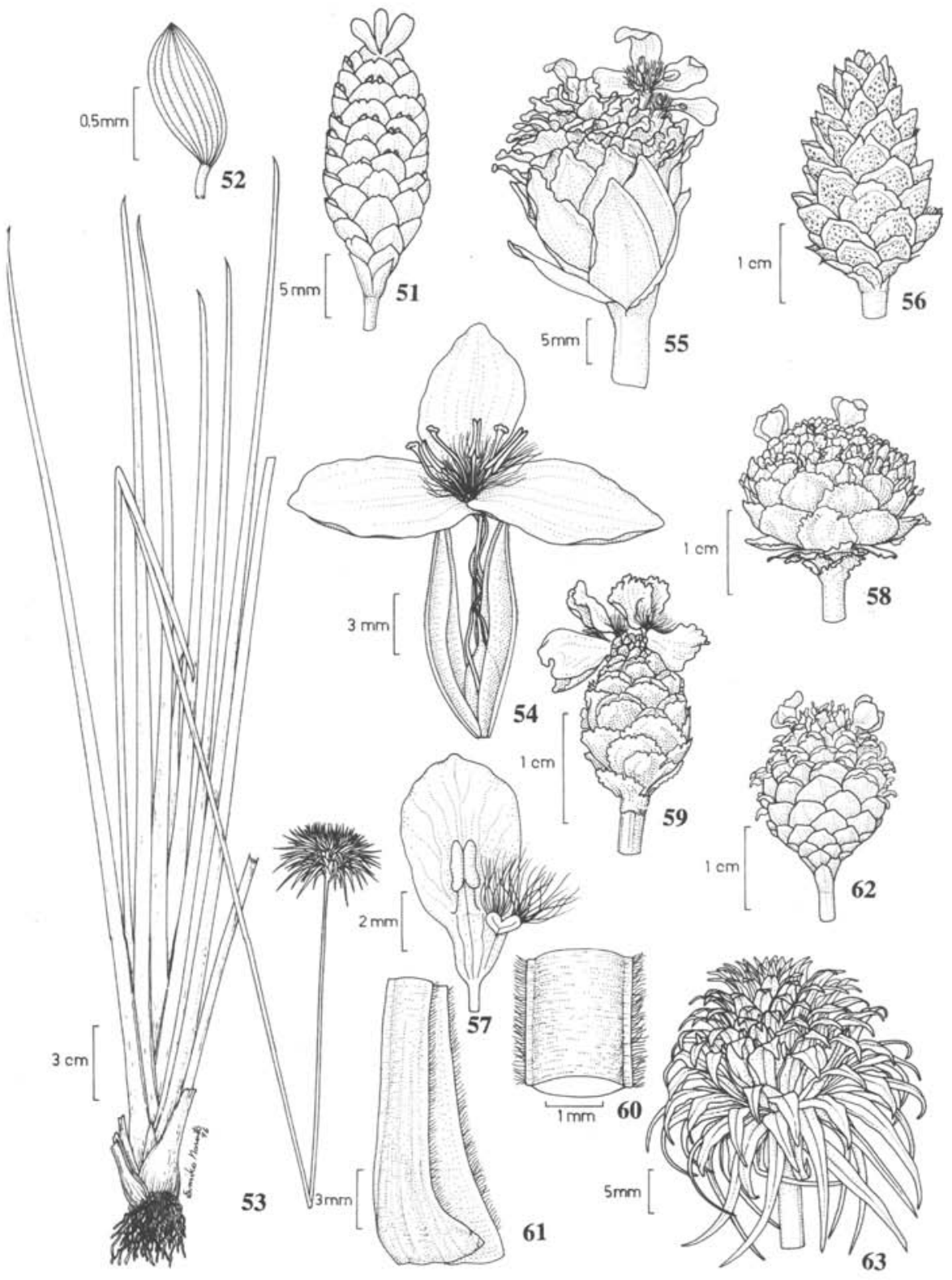

Figura 51.Xyris ciliata: Espiga. Fig 52-54. Xyris cipoensis: 52. Semente; 53. Hábito; 54. Flor. Fig. 55. Xyris coutensis: Espiga. Fig. 56-57. Xyris laxifolia: 56. Espiga; 57. Pétala com estame e estaminódio. Fig. 58. Xyris platystachia: Espiga. Fig. 59-61. Xyris roraimae: 59. Espiga; 60. Detalhe do fragmento do escapo mostrando costelas ciliadas; 61. Base da bainha foliar. Fig. 62. Xyris spectabilis: Espiga. Fig. 63. Xyris sp.: Espiga. 
lacerado-fimbriada no ápice, maiores que as brácteas. Placentação basal. Semente elipsóide, multicostada, $0,6 \mathrm{~mm}$ compr.

Material examinado. BAHIA: Mucugê, margem da estrada Andaraí-Mucugê, estrada nova, $20 \mathrm{~km}$ Mucugê, J.R.Pirani et al., CFCR 1638, 21/VII/1982 (SP, SPF); $15 \mathrm{~km} \mathrm{~N}$ de Mucugê, S da ponte do Rio Piaba, $R$. Kral et al. 72859, 21/VII/1985 (SP, VDB); ca. 6 km N de Mucugê, pela estrada para Andaraí, R. Kral et al. 72883, 22/VII/1985 (SP, VDB); $3 \mathrm{~km} \mathrm{~S}$ da ponte do Rio Piaba, $\mathrm{N}$ de Mucugê, na estrada para Andaraí, $R$. Kral et al. 72900, 23/VII/1985 (SP, VDB); Rio de Contas, Morro da Cruz, na base do Pico das Almas, M.G.L.Wanderley et al. 892, 14/VII/1985 (SP); Serra da Larguinha, M.G.L.Wanderley et al. 919, 19/VIL/1985 (SP); Serra da Larguinha, ca. $15 \mathrm{~km} \mathrm{~S} \mathrm{de}$ Palmeiras, estrada Palmeiras-Capão, R.Kral et al. 72832, 19/VIL/1985 (SP, VDB).

Xyris ciliata caracteriza-se pelas espigas castanho-escuras e cilíndricas, ocorrendo nas restingas do leste do Brasil, desde o Estado de Pernambuco até Espírito Santo e Rio de Janeiro (Smith \& Downs 1968). É freqüente nos campos rupestres da Bahia e de Minas Gerais. Floresce no mês de julho.

2. Xyris cipoensis Smith \& Downs, Jour. Washington Acad.Sci. 44: 311. 1957. Figuras 52-54.

Nome vulgar: coroinha.

Ervas perenes, cespitosas, rizomatosas. Raízes espessas. Folhas dísticas a espiraladas, (15) 30-70 cm compr.; lâmina ensiforme, ca.18cm compr., ápice agudo, margens ciliado-escabras; bainhas castanho-escuras a quase negras em direção à base, margens ciliadas, lígula ausente. Bainha do escapo 30-37 cm compr., conduplicada, carenada, margens ciliadas, lâmina curta. Escapo sem costela ou unicostelado, (26) $40-95(100) \mathrm{cm}$ compr., costela quando presente híspida. Espiga globosa, multiflora (+ 40 flores), 1,5-3,5 X 1-3,5cm ; brácteas estéreis numerosas 33-35, eretas na espiga jovem e revolutas na antese, coriáceas, castanhas, concolores ou com margem estreita, hialina e amarelada, algumas vezes inconspicuamente laceradas e fimbriadas, 1,5-2,5 $\mathrm{X} 0,2-0,4 \mathrm{~cm}$, as basais lanceolado-triangulares, menores, as medianas ovado-lanceoladas, ápice levemente carenado e retroflexo, as florais cocleadas, mais curtas e levemente mais largas que as estéreis, 1,2-1,5cm compr.; sépalas laterais lanceoladas, livres, inequilaterais, carena ciliada. Placentação basal. Semente elipsóide, multicostada, $0,6 \mathrm{~mm}$ compr.

Material examinado: MINAS GERAIS. Santana do Riacho, Serra do Cipó, rodovia Belo Horizonte-Conceição do Mato Dentro, km 98, M.G.L.Wanderley, CFSC 5488, 04/VII/1978 (SP); km 103 e 104, H.C. Lima 427, 26/IV/1978, (RB); km 112, R.Kral et al. 73006, 1/III/1985 (SP, SPF); km 112-128, B.Maguire et al. 49073, 07/VII/1960 (NY); km 115, Mello-Barreto 4357, 06/VIII/1933. (R, RB, US); km 126, M.G.L. Wanderley; CFSC 11094, 1/V/1988, (SP). 
Pela presença de espigas vistosas esta espécie constitui uma das principais "sempre-vivas" da família, sendo vendida nos depósitos de Datas e Gouveia, em Minas Gerais. Endêmica da Serra do Cipó, ocorre entre os km 102 e 127 em altitudes de 1060 a 1330 m, juntamente com outras espécies de Xyris e de Cephalostemon riedelianus Koern. (Rapateaceae). Floresce e frutifica entre os meses de maio e dezembro.

3. Xyris coutensis Wand. \& Cerati, Brittonia 39(2): 298-301.1987.

Figuras 55, 64.

Nomes vulgares: cacau, coroa-cacau.

Ervas cespitosas. Caule curto. Raízes espessas. Folhas basilares, dísticas, ensiformes, 15-32 X 0,7cm, estriadas, com pontuações avermelhadas, margens híspidas, ápice assimétrico-obtuso; bainhas foliares paleáceas, carenadas, carena híspida, distintamente dilatadas na base e castanho-escuras, margens diferenciadas, estreitas, membranáceas; lâminas 7,5-16cm compr. Bainha do escapo 20-47cm compr. Escapo cilíndrico, glabro, levemente estriado, $60-120 \mathrm{~cm}$ compr. Espiga capituliforme, multiflora, (+ 10 flores), 1,5-2 X 1,5-2,5cm; brácteas involucrais numerosas, longotriangulares, castanho-escuras a negras, margens distintas, estreitas, amareladas, ápice agudo, as basais carenadas no ápice, ca. $1 \mathrm{~cm} \mathrm{X} 0,5 \mathrm{~cm}$, as medianas $1,2-2 \times 0,5 \mathrm{~cm}$, as florais $0,9-1,5 \times 0,5 \mathrm{~cm}$; sépalas laterais livres, delicadas, $0,9 \mathrm{~cm}$, inequilaterais, carenadas para o ápice, carena larga e serrilhada; estames sagitiformes, antera ca. 1,5mm; ovário estreito elíptico. Placentação basal. Semente estriada.

Material examinado: MINAS GERAIS: Couto de Magalhães, Chapada do Couto, M.G.L.Wanderley et al. 707, 17/VII/1984 (holótipo: SP; isótipos: K, SPF, VDB).

Xyris coutensis é uma das espécies mais ornamentais do gênero, destacando-se pelas espigas capituliformes e brácteas longo-triangulares, castanho-escuras a negras que deram origem ao nome popular de "cacau". É bastante apreciada pelos vendedores de "sempre-vivas" de Minas Gerais. Entretanto, pelo excessivo extrativismo é atualmente encontrada em pequenas quantidades nos entrepostos de vendas, sendo rara e ameaçada de extinção (Wanderley \& Cerati 1987).

Apesar de alguns moradores mencionarem a ocorrência desta espécie para a Serra das Bandeirinhas, próximo à Serra do Cipó (MG), ela foi coletada apenas na Chapada do Couto, florescendo no mês de julho.

4. Xyris laxifolia Mart., Fl. bras. 3(1): 220. 1885.

Figuras 56-57.

Nome vulgar: botão-marrom.

Ervas cespitosas. Raízes espessas. Folhas basilares, dísticas, flabeliformes, 36- 
$70 \mathrm{X}$ ca. $1 \mathrm{~cm}$; lâminas ca. da metade do compr. da folha, ápice assimétrico-agudo, lígula ausente. Bainha do escapo conduplicada, ca. $30 \mathrm{~cm}$ compr., carenada, sem lâmina. Escapo bicostelado no ápice, 71-150 X 0,4cm larg. Espiga largo-ovóide, 1,5$3,5 \mathrm{~cm} \times 0,9-1,5 \mathrm{~cm}$; brácteas arredondadas com mancha verde-acinzentada conspícua, as basais triangulares, carenadas, menores, $0,4 \times 0,3 \mathrm{~cm}$; as medianas $0,6 \mathrm{X}$ $0,3 \mathrm{~cm}$; brácteas florais fortemente convexas, arredondadas, orbiculares, $0,2 \times 0,6 \mathrm{~cm}$; sépalas livres, espatuladas, subequilaterais, agudas, carenadas, carena ciliada, $0,6 \mathrm{~cm}$ larg.; anteras 1,5mm compr.; estaminódios bifurcados, densamente pilosos. Placentação parietal. Cápsula obovóide. Semente estriada, 0,7-0,9cm compr.

Material examinado. BAHIA: Serra do Sincorá, Lagoa Encantada, 19 km NE de Ibicoara, perto de Brejão, R.M.Harley et al. 15780, 1/II/1974 (K, SP, SPF); Rio de Contas, estrada do Fraga, $2 \mathrm{~km}$ SE da cidade, M.G.L.Wanderley et al. 877, 13/VII/ 1985 (SP). GOIÁS: Alto Paraiso de Goiás, Parque Nacional da Chapada dos Veadeiros, S.Romaniuc Neto \& M.G.Sajo 364, 27/VII/1985 (SP); S.Romaniuc et al. 595, 8/ II/1987 (SP); H.S.Irwin et al. 24818, 21/III/1969 (RB); $20 \mathrm{~km}$ de Ponta Alta do Norte, Rizzo 9891, 13/VI/1974 (SP, UB). MINAS GERAIS: Chapadão de Catuni, F.Barros 57, 3/IV/1980 (SP); Santana do Riacho, Serra do Cipó, km 107 da rodovia Belo Horizonte-Conceição do Mato Dentro, M.G.L.Wanderley, CFSC 9277 (SP); km 121, M.G.L.Wanderley \& M.G. Sajo, CFSC 10991, 27/III/1988 (SP); km 140, A.B.Joly et al., CFSC 1325, 6/III/1972 (SP); Cachoeira próxima a São João da Serra, M.G.L.Wanderley, CFSC 11082, 30/IV/1988 (SP).

Xyris laxifolia é a espécie de sempre-viva das Xyridaceae de maior área de distribuição, ocorrendo de norte a sul do Brasil em ambientes brejosos dos campos rupestres brasileiros ou em locais abertos e perturbados, com solo ácido.

Esta espécie tem sido comercializada em Brasília, formando arranjos florais, juntamente com folhas coriáceas de algumas espécies de dicotiledôneas do cerrado. Floresce de fevereiro a julho.

5. Xyris nigricans Alb. Nilsson, Kongl. Svenska vetenska-Akad. 24 (14): 60. 1892. Figura 64.

Nomes vulgares: botão-coroa, coroa.

Ervas cespitosas. Caule curto. Raízes espessas. Folhas dísticas, ensiformes, 15$35 \times$ X 0,3-0,8cm, nervadas, lâminas ensiformes; ápice assimétrico-obtuso; bainhas foliares com base alargada e castanho-escura; lígula ausente. Bainha do escapo 14-40 $\mathrm{X}$ ca. $2 \mathrm{~cm}$. Escapo cilíndrico, 40-70 cm compr. Espiga globosa, multiflora, (50-60 flores); brácteas involucrais numerosas, vistosas, castanho-escuras, fortemente recurvadas, 0,7-2 X 0,2-0,4cm, distintamente diferenciadas das florais, brácteas florais menores, $1,2 \times 0,4 \mathrm{~cm}$ larg., margem amarela, ápice acuminado; sépalas laterais livres, naviculares, subequilaterais, carenadas, carena ciliada, $0,7-0,9 \mathrm{~cm}$ compr., agudas; lobo da corola ovóide, ca. $10 \mathrm{~mm}$ compr.; anteras oblongas; estaminódios bifurcados, 
densamente pilosos, tricomas moniliformes; ovário obovado. Placentação basal. Semente reticulada, $11-12 \mathrm{~mm}$ compr.

Material examinado: MINAS GERAIS: Santana do Riacho, Serra do Cipó, km 142 ao longo da rodovia Belo Horizonte-Conceição do Mato Dentro, J.Semir et al., CFSC 2726, 19/VII/1972. (SP); km 138,M.G.L.Wanderley; CFSC 5540, 15/VIII/1979 (SP); km 145, R.Kral et al. 72946, 31/VII/1985 (SP).

Xyris nigricans é restrita à Serra do Cipó. Apresenta espigas vistosas com brácteas involucrais castanhas e patentes formando uma coroa com numerosas flores amarelas, densamente agrupadas no centro da inflorescência. A espiga é muito semelhante à de Xyris cipoensis Smith \& Downs ("coroinha"), sendo os caracteres vegetativos mais importantes para a separação das mesmas (Wanderley 1992). Floresce de julho a novembro.

6. Xyris platystachia Alb. Nilsson ex Malme, Bih. Kongl. Svenska vetenska-Akad. 24(3):17. 1898.

Figuras 58, 64.

Nome vulgar: cabeça-de-negro.

Ervas cespitosas. Raízes espessas. Caule curto. Folhas basilares, dísticas, ensiformes, $36,5-50 \mathrm{~cm}$ compr., $4-13 \mathrm{~cm}$ larg., nervadas, ápice agudo-atenuado; bainhas foliares alargadas, castanho-avermelhada na base, lígula ausente. Bainha do escapo com lâmina curtíssima, fortemente carenada, híspidas nas margens, lâmina curta. Escapo cilíndrico a trígono, $85-130 \mathrm{~cm}$ compr. Espiga globosa, multiflora, mais de 40 flores, 1,5-2cm compr., 1,5-2,5cm larg., brácteas involucrais estéreis numerosas (mais de 10), cocleadas, laceradas, margens amareladas, as basais triangulares, carenadas para o ápice, carena ciliado-fimbriada, $0,5 \times 0,5 \mathrm{~cm}$, as medianas ca. $1 \times 0,7 \mathrm{~cm}$, brácteas florais $1,2 \times 0,7 \mathrm{~cm}$; sépalas laterais livres, curvas, ligeiramente inequilaterais, carenadas, ca. $12 \mathrm{~cm}$ compr., obtusas, lobos da corola elípticos; estames sagitiformes, anteras $0,2 \mathrm{~cm}$ compr., estaminódios bifurcados, ramificados, densamente pilosos, tricomas moniliformes; estigmas expandidos no ápice. Cápsula estreito-elíptica, $0,6 \mathrm{~cm}$ compr. Semente reticulada, ca. $1 \mathrm{~mm}$ compr.

Material examinado. MINAS GERAIS: Diamantina, M.G.Sajo \& V.Scatena, CFCR 12671, 29/III/1988 (SP, SPF); Serra de Santo Antônio a oeste da cidade de Diamantina, Filgueiras \& Burman 1088, 19/I/1984 (SP); Santana do Riacho, Serra do Cipó, rodovia Belo Horizonte-Conceição do Mato Dentro, km 127, M.G.L.Wanderley et al., CFSC 9314, 15/V/1982 (SP); km 132, R. Kral et al., 72972, 31/VII/1985 (SP, VDB); km 140, R. Kral et al 72959, 31/VII/1985 (SP, VDB); Serra do Cipó, F.Barros $198,10 / \mathrm{IV} / 1980(\mathrm{SP})$.

Xyris platystachia destaca-se das demais espécies de “sempre-vivas" de Xyrida- 
ceae pelas espigas globosas com um invólucro de numerosas brácteas curtas, castanhas a negras. Floresce entre os meses de março e junho, sendo coletada nos meses de julho, no início da frutificação.

É restrita à Serra do Cipó e de Diamantina, formando extensos campos em locais de solos brejosos.

7. Xyris roraimae Malme, Notizbl. Bot. Gart. Berlin 6: 116. 1914.

Figuras 59-61.

Nome vulgar: bico-de-ouro.

Ervas cespitosas. Caule curto. Folhas ensiformes, dísticas, lanceoladas, ca. $25 \mathrm{X}$ $0,4 \mathrm{~cm}$, lâminas lanceoladas, assimétrico-agudas, nervadas, transverso-rugulosas, margens híspidas; bainha foliar carenada, lígula membranácea, arredondada. Bainha do escapo conduplicada, carenada, $10-14 \mathrm{~cm}$ compr., lâmina curta, $0,5 \mathrm{~cm}$ compr. Escapo aplanados, bicostelado, costelas híspidas, $58-68,5 \mathrm{~cm}$ compr., 1,2 $\mathrm{mm}$ larg. Espigas multifloras, ca. 25 flores, ovóides, $1-1,7 \mathrm{~cm} \mathrm{X} \mathrm{ca.} 1 \mathrm{~cm}$; brácteas estéreis $0,5-0,6 \mathrm{X} 0,3-$ $0,4 \mathrm{~cm}$ compr., castanhas, cocleadas, margens estreitas, patentes, laceradas e avermelhadas, as basais mais curtas que as medianas, carenadas para o ápice, as medianas arredondadas, as florais semelhantes às medianas, $0,7 \mathrm{~cm}$ compr.; sépalas livres, fortemente inequilaterais, 1,5-2 mm larg., maiores que as brácteas, espatulado-lanceoladas, carena larga com tricomas espessos, roxo-ferrugíneos para o ápice, ca. $7 \mathrm{~mm}$ compr.; lobos da corola ca. $4 \mathrm{~mm}$ compr.; estames $0,4 \mathrm{~cm}$ compr.; anteras $1,5 \mathrm{~mm}$ compr., estaminódios bifurcados, longo-pilosos. Cápsula ovóide, ca. $4 \mathrm{~mm}$ compr. Semente estriada, $0,8 \mathrm{~mm}$ compr.

Material examinado. BAHIA: Rio de Contas, Pico das Almas, Morro da Cruz, M.G.L. Wanderley et al. 892, 14/VII/1985 (SP). GOIÁS: Alto do Paraíso de Goiás, Reserva Federal da Chapada dos Veadeiros, S.Romanuic Neto \& M.G.Sajo 304, 25/VII/1985 (SP). DISTRITO FEDERAL: Brasília, Fazenda Água Limpa, M.C.Kirkbride 1522, 20/VI/1981 (SP). MINAS GERAIS: Couto de Magalhães, Fazenda das Abóboras, $M$. G.L. Wanderley et al., CFCR 4578, 16/VII/1984 (SP, SPF); Grão-Mogol, Vargem do Quartel, 8 km da cidade, M.G.L.Wanderley et al. 858, 10/VII/1985 (SP); Diamantina, J.Y.Tamashiro et al. 17413, 4/III/1985 (UEC); Joaquim Felício, Serra do Cabral, Morro da Onça, M.G.L.Wanderley et al. 800, 6/VII/1985, (SP); Santana do Riacho, km 110, M.G.L.Wanderley et al. 539, 14/VI/1982 (SP).

Xyris roraimae, conhecida anteriormente apenas para a Venezuela, Guiana Francesa e Pico Roraima, no Brasil, foi coletada mais recentemente em Minas Gerais, Bahia, Goiás e Distrito Federal.

As espigas de ovóides a cilíndricas e as brácteas com margens avermelhadas e patentes tornam esta espécie de sempre-viva bastante caracteristica e ornamental.É pouco explorada comercialmente em Minas Gerais e Bahia, sendo mais vendida em Brasília, juntamente com outras espécies do Distrito Federal e de Goiás. 


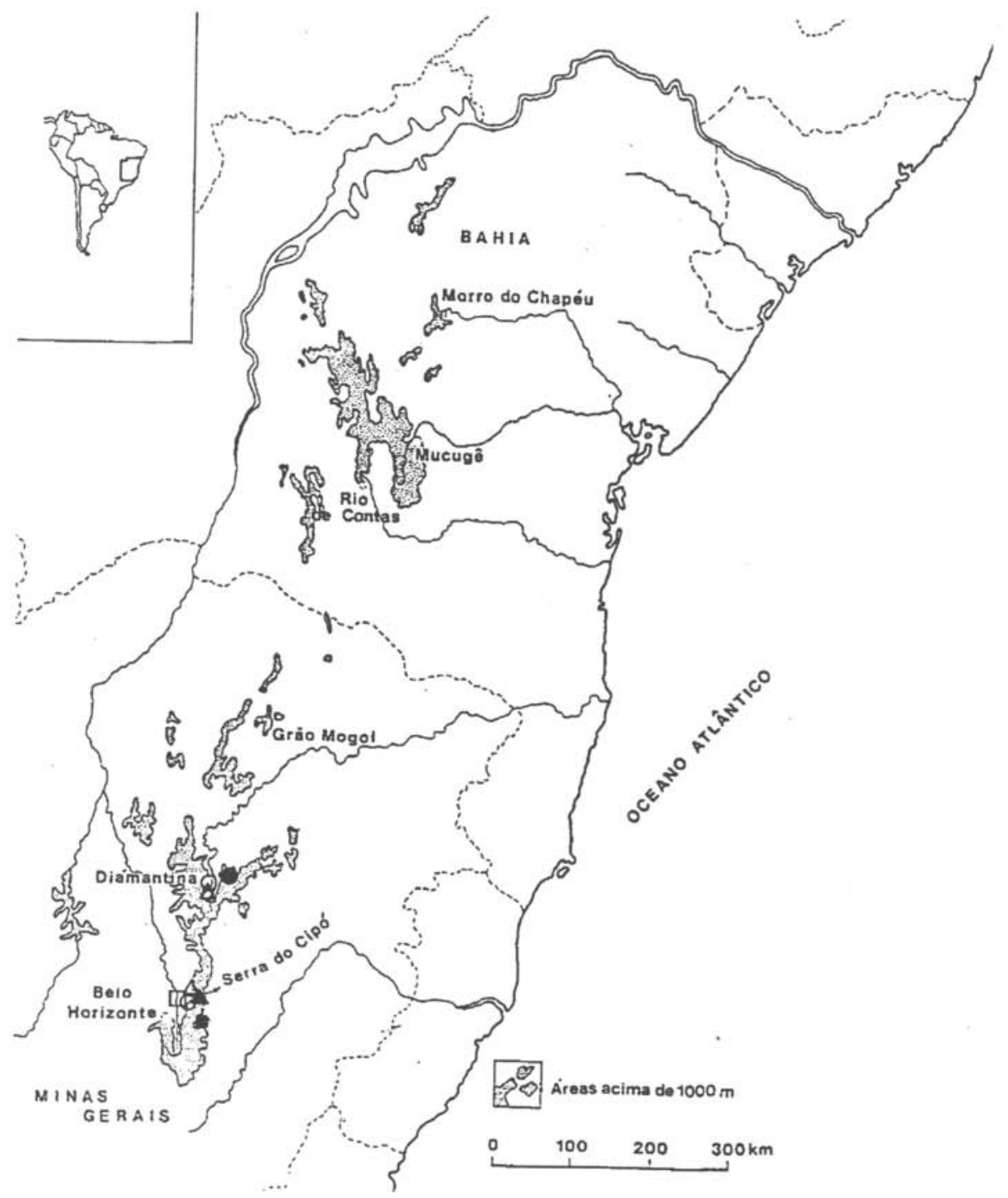

Figura 64. Mapa da Cadeia do Espinhaço, Brasil, mostrando a distribuição geográfica de algumas espécies: Xyris cipoensis $\boldsymbol{\Lambda} ; X$. coutensis $\bullet$; X. platystachia $O$; X. spectabilis $\Delta ; X$. nigricans $\square$, Xyris sp. 
8. Xyris spectabilis Mart., Flora 24.2: 54. 1841.

Figuras 62, 64.

Nomes vulgares: botão-marrom, cabeça-de-negro.

Ervas cespitosas, bulbosas. Raízes fibrosas. Folhas basilares, dísticas, ensiformes, $13-22 \mathrm{~cm}$ compr. 0,5cm larg.; bainhas ca. da metade do comprimento total da folha, lâminas nervadas, ápice assimétrico-agudo, alargadas na base, castanho-escuras e carenadas. Bainha do escapo fortemente carenada, ca. $20 \mathrm{~cm}$ compr., lâmina curta, $0,5 \mathrm{~cm}$ compr. Escapo cilíndrico, levemente estriado, $65 \times 0,3 \mathrm{~cm}$. Espiga multiflora, (+20 flores), ovóide a obovóide, $1,5 \times 1 \mathrm{~cm}$; brácteas estéreis numerosas, mais de 10 , castanho-escuras; as basais elípticas, curtas, carenadas, $0,4 \mathrm{~cm} \mathrm{X} 0,2 \mathrm{~cm}$; as medianas orbiculares, cocleadas $0,4-0,7 \mathrm{X} 0,5 \mathrm{~cm}$; brácteas florais semelhantes às medianas, 0,7 X $0,4 \mathrm{~cm}$ levemente laceradas; sépalas visivelmente mais longas que as brácteas, espatuladas, curvas, fortemente inequilaterais, carenadas, obtusas para o ápice, $0,9 \mathrm{~cm}$ compr., lobos da corola estreito-obovóide, margens laceradas, $0,8 \times 0,3 \mathrm{~cm}$; estaminódios bifurcados, densamente pilosos; estames sagitiformes, $0,3 \mathrm{~cm}$ compr., anteras $0,2 \mathrm{~cm}$ compr. Cápsula obovóide, $0,5 \mathrm{~cm}$ compr.

Material examinado: MINAS GERAIS: Couto de Magalhães, Fazenda das Abóboras, M.G.L.Wanderley et al., CFCR 4580, 16/VII/1984 (SP); M.G.L.Wanderley et al., CFCR 4603, 17/VII/1984 (SP, SPF); Joaquim Felício, Serra do Cabral, Bocaina, M.G.L.Wanderley et al. 785, 5/VII/1985 (SP); ca. 15 km de Joaquim Felício, M.G.L.Wanderley et al. 815, 7/VII/1985 (SP); R.Kral et al. 72595, 5/VII/1985 (SP, VDB); R.Kral et al 72672, 7/VII/1985 (SP,VDB); Morro do Jucão, R.Kral et al., 72655, 7/VII/1985 (SP, VDB); Diamantina, N.L. Menezes et al., CFCR 108, 18/VII/ 1980 (SP, SPF).

Xyris spectabilis é freqüente nos campos rupestres da Bahia e de Minas Gerais, florescendo no mês de julho.

É próxima de Xyris aurea Smith \& Downs, apresentando como esta, espigas multifloras e sépalas maiores que as brácteas. Diferenciam-se entre si pelo tamanho e forma das espigas, sendo globosas e menores em Xyris aurea e ovóides e maiores em Xyris spectabilis.

\section{Xyris sp.}

Figuras 63, 64.

Nome vulgar: abacaxi-dourado.

Ervas cespitosas, rizomatosas, rizoma vertical. Folhas basilares, dísticas, flabeliformes, $57-67 \mathrm{~cm}$ compr., margens escabras; bainhas com base alargada, orbicular, castanho-escura; lâmina ensiforme, ápice assimétrico-obtuso, lígula ausente. Bainha do escapo conduplicada, 3-carenada, $50-77 \mathrm{~cm}$ compr. lâmina curta. Escapo cilíndrico 
a triangular, 1-multicostado, costas escabras, 120-200 X 0,4cm. Espiga vistosa globosa, multiflora (+ 40 flores), 2,5-3 X 3-4cm.; brácteas castanho-claras a castanhoescuras, triangulares, longo-acuminadas, revolutas, margens membranáceas, as estéreis ca. 40 , imbricadas, $2-3 \times 0,3 \mathrm{~cm}$, brácteas florais cocleadas, mais curtas que as externas, $12-16 \mathrm{~mm}$ compr.: sépalas laterais livres, inequilaterais, naviculares, agudas, ca. $11 \mathrm{~mm}$ compr.; lobo da corola ovóide; estames $4,5 \mathrm{~mm}$ compr., antera oblonga, ca. $3 \mathrm{~mm}$ compr. Cápsula obovóide, estreita, ca. $5 \mathrm{~mm}$ compr. Placentação basal, funículos alongados. Sementes numerosas, reticuladas, ca. $13 \mathrm{~mm}$ compr.

Material examinado. MINAS GERAIS: Santana do Riacho, Parque Nacional da Serra do Cipó, Serra da Salitreira, córrego da Água Preta, M.G.L.Wanderley, CFSC 11059, 12/VII/1987 (SP); Serra das Bandeirinhas, caminho para Cachoeira das Flores, M.G.L.Wanderley et al., CFSC 10703, 9/IX/1987 (SP).

Esta espécie é a mais ornamental e de maior valor econômico do gênero. Até o momento, só foi encontrada na Serra do Cipó e na Serra da Bandeirinha, formando populações relativamente pequenas, correndo risco de extinção.

Apesar do local de difícil acesso, é bastante procurada pelos vendedores de "sempre-vivas", sendo colhida no mês de julho, na fase de floração e início de frutificação.

Pertence ao grupo de Xyris nigricans Alb. Nilss. e X. cipoensis Smith \& Downs, pela presença de brácteas estéreis numerosas, longo-triangulares, revolutas e conspícuas. As brácteas amarelo-douradas formam um invólucro muito ornamental, conferindo-lhe o nome popular de "abacaxi-dourado". Trata-se de uma espécie inédita para a Ciência.

\section{Agradecimentos}

Os autores agradecem à FINEP, pelo financiamento deste projeto, e ao Prof. Dr. Paulo Windisch, pela versão inglesa do resumo deste trabalho.

\section{Referências bibliográficas}

Doell, J.C. 1878. Gramineae II. In Martius, C.F.P. (ed.). Flora Brasiliensis 2 (3): 1-242.

Ferreira, M.B. \& Saturnino, H.M. 1977. Algumas consideraçōes sobre os arranjos ornamentais confeccionados com plantas secas em Minas Gerais. In Ferreira, M.B.; del Laca-Buendia, J.P. \& Tenório, E.C. (eds.) Anais do XXVIII Congresso Nacional de Botânica. Belo Horizonte. p. 201-211.

Giulietti, A.M. 1984. Estudos taxonômicos no gênero Leiothrix Ruhl. (Eriocaulaceae). São Paulo: Universidade de São Paulo. Tese de Livre-Docência.

Giulietti, N.; Giulietti, A.M.; Pirani, J.R. \& Menezes, N.L. 1988. Estudos em "sempre-vivas": importância econômica do extrativismo em Minas Gerais, Brasil. Acta bot. bras. I(2): 179-193.

Heringer, E.P.; Barroso, G.M.; Rizzo, J.A. \& J.A.; Rizzini, C.T. 1977. A flora do cerrado. In M.G. Ferri, (coord.) Simpósio sobre cerrado 4, Brasilia, 1976: 211-232. Belo Horizonte: Ed. Itatiaia; São Paulo, EDUSP. 
Moldenke, H.N. 1977. Additional notes on the Eriocaulaceae LXXIII. Phytologia 37 (1): 22-58.

Pirani, J.R. \& Giulietti, A.M. 1989. Flora da Serra do Cipó, Minas Gerais: Rapateaceae. Bolm. Botânica Univ. São Paulo 11: 171-174.

Renvoize, S.A. 1984. The Grasses of Bahia. Kew, Royal Botanic Gardens, Kew. 301 p.

Ruhland, W. 1903. Eriocaulaceae. In Engler, A. (ed.) Das Pflanzenreich 4 (3):1-294. Wilhelm Engelmann. Leipzig.

Saturnino, H.M.; Saturnino, M.A.C. \& Ferreira, M.B. 1977. Algumas consideraçōes sobre exportação e importação de plantas ornamentais em Minas Gerais. In M.B. Ferreira,; J.P. del Laca-Buendia, \& E.C. Tenório, (eds.) Anais do XXVIII Congresso Nacional de Botânica. Belo Horizonte. p. 213-217.

Smith, L. B. \& Downs, R. 1968. Xyridaceae. In F. C. Hoehne, (ed.) Flora Brasilica 9(12):1-211.

Smith, L.B.; Wasshausen, D.C. \& Klein, R.M. 1981. Gramíneas. Flora Ilustrada Catarinense (Gram.): 1 435.

Smith, L.B.; Wasshausen, D.C. \& Klein, R.M. 1982. Gramíneas. Flora Ilustrada Catarinense (Gram.): 516-538.

Wanderley, M.G.L. 1992. Estudos taxonômicos no gênero Xyris L. (Xyridaceae) da Serra do Cipó, Minas Gerais, Brasil. São Paulo: Universidade de São Paulo. Tese de doutorado.

Wanderley, M.G.L. \& Cerati, T.M. 1987. Studies in Xyridaceae II. Two new species of Xyris from Brazil. Brittonia 39:298-301. 